\title{
1 Late Pleistocene glaciations of the arid subtropical Andes and new results from the
}

2 Chajnantor Plateau, northern Chile

3

4 Dylan J. Ward

5 Jason M. Cesta

6 University of Cincinnati, Dept. of Geology, Cincinnati, OH 45221

7

8 Joseph Galewsky

9 University of New Mexico, Dept. of Earth and Planetary Sciences, Albuquerque, NM, USA

$10 \quad 87131$

11

12 Esteban Sagredo

13 Pontificia Universidad Católica de Chile, Santiago, Chile

14 Millennium Nucleus PaleoClimate

15

16 Correspondence to:

17 Dr. Dylan J. Ward

18 Dept. of Geology

19 University of Cincinnati

20 ML0013

21 Cincinnati, OH, USA 45221

22 Ph.: 1-513-556-2174

23 Dylan.Ward@uc.edu

24

25 Key words: Glacial deposits, paleoclimatology, cosmogenic dating, arid Andes, Altiplano, Last 26 Glacial Maximum 


\section{Abstract}

The spatiotemporal pattern of glaciation along the Andes Mountains is an important proxy record reflecting the varying influence of global and regional circulation features on South

31 American climate. However, the timing and extent of glaciation in key parts of the orogen,

32 particularly the deglaciated arid Andes, are poorly constrained. We present new cosmogenic ${ }^{10} \mathrm{Be}$

33 and ${ }^{36} \mathrm{Cl}$ exposure ages for glacial features on and near the Chajnantor Plateau $\left(23^{\circ} \mathrm{S}\right)$. The new

34 dates, although scattered due to cosmogenic inheritance, imply that the most recent extensive

35 glacial occupation ended before or during the global Last Glacial Maximum (LGM). We discuss

36 this new record in the context of published glacial chronologies from glacial features in Peru,

37 Bolivia, and northern Chile rescaled using the latest cosmogenic ${ }^{10}$ Be production rate calibration

38 for the tropical Andes. The results imply regionally synchronous moraine stabilization ca. 25-40

$39 \mathrm{ka}, 15-17 \mathrm{ka}$, and 12-14 ka, with the youngest of these moraines absent in records south of

$40 \sim 20^{\circ} \mathrm{S}$, including in our new Chajnantor area chronology. This spatial pattern implicates easterly

41 moisture in generating sufficient snowfall to glaciate the driest parts of the Andes, while

42 allowing a role for westerly moisture, possibly modulated by the migration of the Southern

43 Westerly Wind belt, in the regions near and south of the Atacama Desert.

2. Introduction

49 the Andes, reflecting the spatial and temporal changes to climate factors that influence

50 glaciation, chiefly temperature and precipitation (e.g., Sagredo et al., 2014). Along the strike of 
51 the range, the relative influence of the major global (Hadley) circulation features changes. These

52 larger-scale patterns are modulated by regional systems (e.g., the South American Summer

53 Monsoon; Baker and Fritz, 2015) and by apparent teleconnections with longer-range climatic

54 drivers such as Northern hemisphere Heinrich events (Kanner et al., 2012) or Antarctic polar

55 front migration (Moreno et al., 2009). Accordingly, the history of glaciation along the length of

56 the Andes is germane to understanding linkages between modern climate systems as well as the

57 global progression of regional climate changes during major climate transitions (e.g., periods of

58 glaciation, deglaciation, and abrupt warming; e.g., Rodbell et al., 2009; Denton et al., 2010).

59 However, in many parts of the Andes, the timing and extent of glaciation is poorly constrained.

60 The arid subtropical Andes, between $18^{\circ} \mathrm{S}$ and $27^{\circ} \mathrm{S}$, are presently deglaciated, even on

61 mountains higher than $6 \mathrm{~km}$. A few studies (e.g., Jenny et al., 1996) have documented moraines,

62 glaciated bedrock, and other glacial features between $18^{\circ} \mathrm{S}$ and $23^{\circ} \mathrm{S}$, but there is little age control

63 on these features, particularly in the area of the Chilean Altiplano (Zech et al., 2008; Rodbell et

64 al., 2009). It is therefore unknown how the timing of glaciation here relates to the increasingly

65 well-documented timing of glaciation in Patagonia (e.g., Ackert et al., 2008; Kaplan et al., 2011),

66 tropical Peru (e.g., Smith et al., 2008; Jomelli et al., 2014; Kelly et al., 2015), and parts of the

67 Bolivian Altiplano (e.g., Smith et al., 2008; Blard et al., 2009). Given the high precipitation

68 sensitivity of the nearest adjacent groups of modern glaciers (Sagredo et al., 2014), and the

69 overall aridity of the region, it is a fair assumption that the former glaciation of the Chilean

70 Altiplano was modulated at least in part by precipitation changes (e.g., Kull and Grosjean, 2000).

71 However, the area is much farther from oceanic moisture sources than the western Peru

72 cordilleras or the glaciated Chilean peaks south of $\sim 30^{\circ} \mathrm{S}$, and far from the eastern Andean

73 foothills and Amazon Basin moisture as well. It is not clear whether past glaciers in the Chilean 
74 Altiplano should have responded similarly to glaciers more directly affected by one or another of 75 these moisture sources.

76 Here, we report unambiguous evidence for the prior presence of a $>200 \mathrm{~km}^{2}$ ice cap on the

77 5-km-high Chajnantor Plateau $\left(23^{\circ} \mathrm{S}\right)$ and a new hybrid cosmogenic ${ }^{10} \mathrm{Be}$ and ${ }^{36} \mathrm{Cl}$ chronology for

78 glacial features in this arid, presently unglaciated part of the Andes. The new dates and the

79 mapped glacial features suggest that this region last deglaciated early during Marine Isotope

80 Stage 2 (MIS 2: 29-14 ka; Lisiecki and Raymo, 2005) and before the global Last Glacial

81 Maximum (here taken as $21 \mathrm{ka}$ ). The Chajnantor Plateau site appears to be located near a

82 transition within regional-scale patterns of glacier response to climatic changes, which we

83 document here by compiling published cosmogenic ${ }^{10} \mathrm{Be}$ and ${ }^{3} \mathrm{He}$ chronologies of latest

84 Pleistocene glacial deposition in the Andes from $10^{\circ} \mathrm{S}$ to $30^{\circ} \mathrm{S}$.

\section{3. Field area geology and modern climate}

\section{3.1. Geology and geomorphology}

88 The Chajnantor Plateau $\left(23.00^{\circ} \mathrm{S}, 67.75^{\circ} \mathrm{W}\right)$ is a high $(5000 \mathrm{~m})$, arid volcanic plateau in the

89 Andes of northern Chile (Fig. 1) that hosts several astronomical observatories, including the

90 Atacama Large Millimeter/Submillimeter Array (ALMA) radio telescope. Its broad, domelike

91 topography was constructed by late Cenozoic volcanism (Schmitt et al., 2001), and most of the

92 plateau is capped by the 1.3 Ma Cajón ignimbrite (Ramírez and Gardeweg, 1982). Many 5600-

$935700 \mathrm{~m}$ stratovolcanoes and lava domes of the Purico Complex (pyroclastic shield) ornament the

94 plateau (Fig. 2). The active stratovolcano Láscar $(5592 \mathrm{~m})$ lies $35 \mathrm{~km}$ south of the Chajnantor

95 Plateau. Extending approximately $100 \mathrm{~km}$ to the north of the Chanjantor Plateau is the Cordillera

96 del Tatio (Fig. 2), a range of previously glaciated, 5000-5500 m volcanic peaks along the Chile- 
97 Bolivia border. The well-known Tatio geyser field lies at $\sim 4300 \mathrm{~m}$ on the western flank of these

98 mountains. South of the geyser field, the Cordillera del Tatio includes a pancake-like dacite

99 dome extrusion which we refer to as Cerro Torta; below, we present dating results from moraines

100 near this extrusion in addition to those from the Chajnantor Plateau.

101 The western flank of the Chajantor Plateau is onlapped by salt and sediment deposits of the

102 Salar de Atacama, a $\sim 4,500 \mathrm{~km}^{2}$ salt flat at $2300 \mathrm{~m}$ elevation that extends approximately $100 \mathrm{~km}$

103 to the south from the north end of the plateau. While much of the ignimbrite shield of the

104 Chajnantor Plateau is a bare bedrock surface, locally thick ( $>50 \mathrm{~m})$ deposits are preserved in

105 patches below the volcanic peaks. These are commonly diamictic and likely include lahar and

106 debris flow deposits (Ramirez and Gardeweg, 1982; Cesta, 2015), other volcanogenic sediment,

107 and glacial and periglacial deposits. $\sim 60 \mathrm{~km}$ farther south is Laguna Miscanti, a shallow $(10 \mathrm{~m}$

108 maximum depth), saline lake at $\sim 4500 \mathrm{~m}$ on the western flank of the Cordón de Puntas Negras

109 (Grosjean et al., 2001). Regionally, small salt flats, alpine wetlands, and small lakes exist above

$110 \sim 4000 \mathrm{~m}$, in addition to hot springs and geyser fields. These features are related to complex

111 groundwater circulation in the mountain block, recharged by the meager precipitation (Risacher

112 and Fritz, 2009).

\section{3.2. Glacial features}

115 Glacial features have been previously recognized in the subtropical arid Andes, mostly above $1164000 \mathrm{~m}$ elevation, and many of these were mapped by Jenny et al. (1996). Their mapping

117 identifies three main stages of glaciation, with younger, well-preserved "Stage I" and "Stage II"

118 moraines commonly closely nested, and "Stage III" - older moraines, undivided - which are

119 much less well-preserved and in some cases very distal to the Stage I and II moraines. While age 
120 assignments for the moraines in this area suffer from a lack of published dates, it is clear that this

121 area was extensively glaciated, with at least Stages I, II, and the latest Stage III moraines

122 interpreted to have formed in the late Pleistocene $(<120 \mathrm{ka})$. While the Chajnantor Plateau

123 deposits that are the subject of this study were not part of their mapping, some of these deposits

124 near Cerro Toco, on the northeastern portion of the plateau, were noted by Jenny et al. (1996)

125 and Amman et al. (2001).

126 Better-known moraines near the Chajnantor Plateau lie about $70 \mathrm{~km}$ to the north, among the

127 volcanic peaks above the El Tatio Geysers. These moraines extend $\sim 10 \mathrm{~km}$ to either side of the

128 range crest and have been variously assumed to date to the time of the global LGM (Graf, 1991;

129 Grenon, 2007), or to late glacial times (Kull and Grosjean, 2000; Amman et al., 2001). Absolute

130 ages for these features have not been published.

132 3.3. Modern regional climate

133 The modern mean annual temperature on the Chajnantor Plateau is between $-3^{\circ}$ and $-4{ }^{\circ} \mathrm{C}$, 134 and a discontinuous $50 \mathrm{~cm}$ permafrost layer exists above $5350 \mathrm{~m}$ (Grenon, 2007). The modern 135 annual precipitation is too low to support glaciers: the upper elevations of the plateau receive 136 between 200 and $350 \mathrm{~mm} / \mathrm{yr}$ of water-equivalent precipitation (Grosjean et al., 2001; Grenon, 137 2007), with high interannual variability (e.g., Garreaud and Aceituno, 2001; Houston, 2006).

138 Much of this precipitation falls during austral summer and is derived from moist air transported 139 from the east, arriving from the tropical Atlantic via the Amazon Basin. This moisture promotes 140 summer rain and snow and occasional damaging floods (Mather and Hartley, 2005; Houston, 141 2006). Because of the very low humidity, high winds, and high insolation, most of the snow that 
142 does fall is quickly swept into depressions, where it sublimates. In most years, any snow cover is 143 gone by August.

144 The overall aridity of the Altiplano and subtropical Andes is maintained primarily by the

145 large-scale subtropical downwelling and cold oceanic upwelling along the west coast of South 146 America related to the Humboldt Current (e.g., Hartley, 2003). An important component of the 147 regional climate is related to the South American Summer Monsoon (SASM), which promotes 148 heavy rainfall in the central Amazon Basin (e.g. Cook and Vizy, 2006). Latent heating associated

149 with the monsoon induces an upper-level high-pressure system called the "Bolivian High" over 150 the subtropical Andes centered around $19^{\circ} \mathrm{S}, 60^{\circ} \mathrm{W}$ (Lenters and Cook, 1997; Fig. 1). In the 151 modern climate, inter- and intra-annual wet periods in the Altiplano correspond to southward 152 displacements of the Bolivian High (Vuille et al., 1998; Garreaud and Aceituno, 2001). This 153 shifts upper-level easterly winds southward, enhancing moisture transport from the east into the

154 Altiplano and arid Andes (Garreaud, 2000). The basic climatology of the region is also 155 modulated by the El Nino/Southern Oscillation (ENSO), which induces circulation anomalies 156 over South America and is associated with regionally heterogeneous precipitation anomalies

157 (e.g., Vuille, 1999; Garreaud and Aceituno, 2001).

\subsection{Nonglacial paleoclimate proxy records}

160 The longest paleoclimate record in the immediate vicinity of our study area comes from a

161106 ka salt core dated by U-series from the Salar de Atacama (Bobst et al., 2001). Generally, wet 162 and dry phases of the Salar are synchronized with those interpreted from the Sajama ice cap drill 163 core $\left(18^{\circ} \mathrm{S}, 6542 \mathrm{~m}\right)$ and the Salar de Uyuni $\left(20^{\circ} \mathrm{S}, 3700 \mathrm{~m}\right)$, both in adjacent Bolivia (Baker et 164 al., 2001; Placzek et al., 2013). Wet phases appear in these records near 70, 45, and 20 ka, with 
165 further enhancement ca. 17-14 ka (the Tauca highstand; Sylvestre et al., 1999). These major 166 phases are also observed in speleothem records from Brazil (Cruz et al., 2005, 2006; Wang et al., 167 2006, 2007) and Peru (Kanner et al., 2012), wherein they are attributed to an orbitally-driven 168 insolation control on precipitation related to modulation of the SASM.

169 Similarly, based on pollen in rodent middens at Quebrada del Chaco, Chile (25.5 $\mathrm{S})$,

170 Maldonado et al. (2005) infer increased winter (westerly) precipitation during the periods $>52$, 171 40-33 ka, 24-17 ka, more precipitation in both seasons 17-14 ka, and more summer (easterly)

172 precipitation from $14-11 \mathrm{ka}$. Other regional proxy records include a $\sim 26.5 \mathrm{ka}$ sediment core from 173 Laguna Miscanti (Grosjean et al., 2001) and diatomaceous deposits and rodent middens 174 associated with river-margin wetlands in the Atacama Desert (Rech et al., 2002; Latorre et al., 175 2006; Quade et al., 2008; Gayo et al., 2012). These records also indicate wet periods during 176 MIS $2(\sim 26.5-22 \mathrm{cal} \mathrm{ka})$, the Tauca highstand $(\sim 17.5-15 \mathrm{ka})$, and in late glacial times (13-10 ka). 177 Based on pollen records from the Laguna Miscanti sediments and altitudinal displacement of 178 taxa, during the late glacial wet periods, precipitation is inferred to have been $2-3 x$ higher than 179 modern (up to $\sim 600 \mathrm{~mm} / \mathrm{yr}$ rather than $\sim 200 \mathrm{~mm} / \mathrm{yr}$; Grosjean et al., 2001; Latorre et al., 2006).

180 Taken together, these records suggest that the orbital forcing on the SASM system is 181 responsible for the major periods of moistening in the Altiplano and arid Andes. Overprinting 182 this, the SASM system responds to North Atlantic region climate changes on annual to orbital 183 timescales (e.g., Kanner et al., 2012; Baker and Fritz, 2015), potentially allowing these drivers to 184 modulate Altiplanic moisture. The southern and western extent of the influence of these systems, 185 i.e., where and when over the late Pleistocene they become less important than westerly sources 186 of moisture such as midlatitude storms associated with the Southern Westerly Wind (SWW) belt, 
187 is poorly resolved, largely because of the paucity of continuous, high resolution proxy records in 188 the Atacama Desert and surrounding regions.

\subsection{Glacial climatology}

191 Sagredo and Lowell (2012) used cluster analysis to classify glaciated regions of the Andes

192 into seven distinct climatic groups. Each group differs from the others in the relative influence of

193 total precipitation, temperature, and seasonality of precipitation on glacial equilibrium line

194 altitudes. According to this classification (Fig. 1B), the Chajnantor area lies directly in between

195 the dry outer tropical glaciers (Group 3; western cordilleras of Peru and Bolivia) and subtropical

196 glaciers (Group 4). By the analysis of Sagredo at al. (2014), the dry outer tropical glaciers

197 receive most of their moisture during DJFM - "Bolivian Winter", a similar seasonal pattern to 198 southern outer tropical glaciers (Group 2.2; eastern cordilleras, Cordillera Real), but with less

199 precipitation overall. On the other hand, subtropical glaciers to the south of the climatic region 200 known as the "Arid Diagonal” (De Martonne, 1934) receive more moisture during JJA than

201 during the remainder of the year. The Chajnantor area lies in the deglaciated region near the 202 north edge of the Arid Diagonal, so Sagredo and Lowell (2012) and Sagredo et al. (2014) did not 203 include it in their analysis.

204 Kull and Grosjean (2000) used a dynamical glacier model that employed mass-balance 205 parameters based on local modern lapse rates to simulate a valley glacier matching moraines in 206 the El Tatio area (70 km north of the Chajnantor Plateau). The simulation results suggested that $2071000 \mathrm{~mm} / \mathrm{yr}$ of additional water-equivalent accumulation, dominated by enhanced easterly208 sourced austral summer precipitation, would be needed at high altitudes to generate this glacier 209 (Kull and Grosjean, 2000). We note that local late glacial precipitation estimates (Grosjean et al., 
210 2001; Latorre et al., 2006) do not indicate sufficient precipitation at that time to force this glacier

211 model.

212

213 4. Methods

214 4.1. Geomorphic mapping

215 Former glacier extents were reconstructed by mapping of moraines and drift limits over an

216 area of $50,000 \mathrm{~km}^{2}$ that includes the southern Altiplano and Chajnantor Plateau to the south end

217 of the Salar de Atacama. Regional mapping was performed at a scale of 1:30,000 using the

218 Landsat 8 ETM+ 15-m panchromatic imagery, high-resolution $(40 \mathrm{~cm})$ satellite imagery from

219 Google Earth, and a 90 m digital elevation model from the Shuttle Radar Topography Mission

220 product v.2 (Farr et al., 2007).

221 Detailed mapping of the Chajnantor Plateau was performed at a scale of 1:15,000 using the

222 same LandSat 8 imagery, plus a combination of high-resolution satellite imagery from Google

223 Earth, aerial photographs (1:50,000 from the Chilean Air Force), an 8-m digital elevation model

224 (DigitalGlobe elevation dataset derived from autocorrelation of stereo satellite imagery), and

225 field observations.

226 Moraines and other drift can resemble landslide and volcanic deposits (e.g. dacitic flank

227 flows and lahars) also present in the field area. We distinguish moraines and drift based on

228 appearance, which is consistent throughout the area as determined by field identification in

229 several locations in the Chajnantor Plateau and Cordillera del Tatio. Moraine deposits in this area

230 tend to be thin and have discrete ridges as compared to the more massive, hummocky landslide

231 and volcanic deposits, and the most prominent set of moraine deposits in the region all fall

232 within a relatively restricted elevation band, whereas many landslide and volcanogenic deposits 
233 are found many hundreds of meters lower in elevation. Other glacial and periglacial features,

234 such as felsenmeer, solifluction lobes, and roche moutonnée are present in the field area, but

235 were not mapped because their extent and interpretation is ambiguous in much of the imagery.

237 4.2. Cosmogenic exposure dating

238 In order to constrain the age of glacial deposits identified the Chajnantor area, we collected 239 rock samples for surface exposure $\left({ }^{10} \mathrm{Be}\right.$ and $\left.{ }^{36} \mathrm{Cl}\right)$ analysis. Samples were collected from

240 prominent boulders at the crests of moraine ridges and from glacially sculpted bedrock within the

241 identified former ice margins, using hammer and chisel. We selected our sampling sites

242 carefully, exploiting prominent boulders, knobs and ridges to minimize the chance of snow or

243 sediment shielding, and favoring bedrock sampling locations with preserved glacial striations

244 and polish to demonstrate zero post-glacial erosion. Many moraine boulders were in poor

245 condition and had to be rejected for sampling, limiting the density of boulder samples on each

246 moraine. Moreover, the felsic ignimbrite of the area contains variable amounts of quartz, which

247 we found in some samples to be difficult to separate from volcanic glass and other similar-

248 density phases in sufficient quantities, limiting the number of successful ${ }^{10} \mathrm{Be}$ analyses. Here we

249 report the analysis of twenty individual samples, eighteen from the Chajnantor Plateau and two

250 from a small glaciated valley in the Cerro Torta area $\sim 50 \mathrm{~km}$ to the north. Of these, eight were

251 analyzed for ${ }^{10} \mathrm{Be}$ only, six for ${ }^{36} \mathrm{Cl}$ only, and six analyzed using both isotopes (Table 2). The

252 twelve ${ }^{10} \mathrm{Be}$ samples were prepared at the University of Colorado and University of Cincinnati

253 using community standard methods (derived from Nishiizumi et al. [1984] and Kohl and

254 Nishiizumi [1992]). The twelve ${ }^{36} \mathrm{Cl}$ samples (from Chajnantor Plateau samples) were prepared

255 at the University of Cincinnati and at the Purdue Rare Isotope Measurement (PRIME) Lab. All 
256 AMS measurements were performed at PRIME Lab. Please see Appendix 1 for complete

257 background details of sample localities and preparation, AMS results, ${ }^{36} \mathrm{Cl}$ sample geochemistry, 258 and age calculations.

259 Given that glacial margins fluctuate even under a steady climate (Roe and O'Neal, 2014), it 260 is difficult in all cases to interpret a moraine age as the timing of a glacial advance. A moraine 261 may, for instance, indicate the end of a glacial advance and the beginning of retreat, or reflect a 262 large excursion during a protracted stillstand during a glacial maximum or a smaller excursion 263 during an overall retreat (Anderson et al., 2014). In the absence of additional information, we 264 infer moraine ages to represent abandonment of the moraine (i.e., initiation of glacial retreat), 265 thus placing a minimum limiting age on glacial advances. Bedrock ages are interpreted to 266 represent withdrawal of glacial ice from that specific location during retreat (e.g., Ward et al., 267 2009). In both cases, significant scatter implies either differential erosion between sample 268 locations or variable cosmogenic nuclide inventory inherited from a previous period of exposure. 269 
Table 1. Cosmogenic sample locations

\begin{tabular}{|c|c|c|c|c|c|c|}
\hline Sample & Type & Analysis & Location & $\begin{array}{l}\text { Latitude } \\
\text { (deg S) }\end{array}$ & $\begin{array}{l}\text { Longitude } \\
\text { (deg W) }\end{array}$ & $\begin{array}{l}\text { Elevation } \\
\text { (m) }\end{array}$ \\
\hline Chaj-12 & $\begin{array}{l}\text { Scoured } \\
\text { bedrock }\end{array}$ & ${ }^{10} \mathrm{Be}$ & Central Chajnantor Plateau & 23.03424 & 67.76790 & 4993 \\
\hline Chaj-12-11 & $\begin{array}{l}\text { Scoured } \\
\text { bedrock }\end{array}$ & ${ }^{36} \mathrm{Cl}$ & $\begin{array}{c}\text { Cerro Toco outlet valley, } \\
\text { Chajnantor Plateau }\end{array}$ & 22.96558 & 67.79036 & 5036 \\
\hline Chaj-12-14 & $\begin{array}{l}\text { Moraine } \\
\text { boulder }\end{array}$ & ${ }^{36} \mathrm{Cl}$ & $\begin{array}{c}\text { Cerro Toco outlet valley, } \\
\text { Chajnantor Plateau }\end{array}$ & 22.95100 & 67.81497 & 4706 \\
\hline Chaj-12-15 & $\begin{array}{l}\text { Moraine } \\
\text { boulder }\end{array}$ & ${ }^{36} \mathrm{Cl}$ & $\begin{array}{c}\text { Cerro Toco outlet valley, } \\
\text { Chajnantor Plateau }\end{array}$ & 22.95102 & 67.81488 & 4704 \\
\hline Chaj-P2 & $\begin{array}{l}\text { Scoured } \\
\text { bedrock }\end{array}$ & ${ }^{10} \mathrm{Be}$ & $\begin{array}{l}\text { Cerro Toco outlet valley, } \\
\text { Chajnantor Plateau }\end{array}$ & 22.96393 & 67.80302 & 4931 \\
\hline Tat-3 & $\begin{array}{l}\text { Scoured } \\
\text { bedrock }\end{array}$ & ${ }^{10} \mathrm{Be}$ & Cerro Torta glacial valley & 22.45008 & 67.99693 & 4405 \\
\hline Tat-4 & $\begin{array}{l}\text { Moraine } \\
\text { boulder }\end{array}$ & ${ }^{10} \mathrm{Be}$ & Cerro Torta glacial valley & 22.45470 & 67.99914 & 4533 \\
\hline Chaj-12-06 & $\begin{array}{l}\text { Moraine } \\
\text { boulder }\end{array}$ & ${ }^{36} \mathrm{Cl}$ & Eastern Chajnantor Plateau & 22.98889 & 67.64395 & 4686 \\
\hline Chaj-12-08 & $\begin{array}{l}\text { Moraine } \\
\text { boulder }\end{array}$ & ${ }^{36} \mathrm{Cl},{ }^{10} \mathrm{Be}$ & Eastern Chajnantor Plateau & 22.96808 & 67.66564 & 4708 \\
\hline Chaj-M1 & $\begin{array}{l}\text { Moraine } \\
\text { boulder }\end{array}$ & ${ }^{10} \mathrm{Be}$ & Eastern Chajnantor Plateau & 22.98725 & 67.65284 & 4660 \\
\hline Chaj-M2 & $\begin{array}{l}\text { Moraine } \\
\text { boulder }\end{array}$ & ${ }^{36} \mathrm{Cl}$ & Eastern Chajnantor Plateau & 22.95012 & 67.68478 & 4796 \\
\hline Chaj-M3 & $\begin{array}{l}\text { Moraine } \\
\text { boulder }\end{array}$ & ${ }^{10} \mathrm{Be}$ & Eastern Chajnantor Plateau & 22.94925 & 67.68583 & 4802 \\
\hline Chaj-12-03 & $\begin{array}{l}\text { Scoured } \\
\text { bedrock }\end{array}$ & ${ }^{36} \mathrm{Cl},{ }^{10} \mathrm{Be}$ & Northern Chajnantor Plateau & 22.91785 & 67.76319 & 4791 \\
\hline Chaj-12-04 & $\begin{array}{l}\text { Scoured } \\
\text { bedrock }\end{array}$ & ${ }^{36} \mathrm{Cl},{ }^{10} \mathrm{Be}$ & Northern Chajnantor Plateau & 22.91783 & 67.76243 & 4789 \\
\hline Chaj-12-18 & $\begin{array}{l}\text { Moraine } \\
\text { boulder }\end{array}$ & ${ }^{36} \mathrm{Cl},{ }^{10} \mathrm{Be}$ & Western Chajnantor Plateau & 23.02044 & 67.83226 & 4576 \\
\hline Chaj-12-19 & $\begin{array}{l}\text { Scoured } \\
\text { bedrock }\end{array}$ & ${ }^{36} \mathrm{Cl},{ }^{10} \mathrm{Be}$ & Western Chajnantor Plateau & 23.01647 & 67.81591 & 4730 \\
\hline Chaj-12-20 & $\begin{array}{l}\text { Moraine } \\
\text { boulder }\end{array}$ & ${ }^{36} \mathrm{Cl}$ & Western Chajnantor Plateau & 23.01366 & 67.81439 & 4758 \\
\hline Chaj-12-21 & $\begin{array}{l}\text { Scoured } \\
\text { bedrock }\end{array}$ & ${ }^{36} \mathrm{Cl},{ }^{10} \mathrm{Be}$ & Western Chajnantor Plateau & 23.01327 & 67.81017 & 4791 \\
\hline Chaj-13 & $\begin{array}{l}\text { Scoured } \\
\text { bedrock }\end{array}$ & ${ }^{10} \mathrm{Be}$ & Western Chajnantor Plateau & 23.02242 & 67.82928 & 4585 \\
\hline Chaj-M5 & $\begin{array}{l}\text { Moraine } \\
\text { boulder }\end{array}$ & ${ }^{10} \mathrm{Be}$ & Western Chajnantor Plateau & 23.02380 & 67.83113 & 4569 \\
\hline
\end{tabular}




\subsection{Age calculations}

275 Conversion of ${ }^{10} \mathrm{Be}$ concentrations to exposure ages was performed using the community276 standard CRONUS-Earth online calculator (Balco et al., 2008;

277 http://hess.ess.washington.edu/math/; v.2.2, accessed 17 December, 2014). Input tables are 278 provided as supplemental digital files. Terrain shielding was not a significant factor in our field 279 area; our most-shielded sample site was calculated to have a terrain correction factor of $0.2 \%$. As 280 this is an order of magnitude below AMS measurement error, no corrections for shielding were 281 applied except where local shielding or self-shielding were measured as noted in the data tables 282 (Appendix 1).

283 A significant challenge involving cosmogenic dating in our field area is that the various 284 commonly-used production rate scaling schemes (e.g., Lal/Stone (Lal, 1991; Stone, 2000); Dunai 285 [2001] (Dunai, 2001); Desilets [2003, 2006] (Desilets and Zreda, 2003; Desilets et al., 2006); 286 and Lifton [2005] (Lifton et al., 2005)) agree fairly well at high latitudes and low altitudes, but 287 the Lal/Stone scheme in particular returns older ages than the other schema for sites at low 288 latitudes and high altitudes. Recent work by Lifton (2014) points out systematic biases in the 289 neutron monitor data upon which all but the Lal/Stone method are based and highlights new 290 radiation modeling (Sato et al., 2008) that brings the various scaling schemes into good 291 agreement, even for calibration sites at low latitudes and high altitudes. Pending a community292 standard calculation scheme for ${ }^{10} \mathrm{Be}$ exposure ages using the Lifton/Sato scaling method, we 293 used a new calibration of the time-dependent Lal/Stone scaling scheme based on co-dated ${ }^{3} \mathrm{He}$ 294 and ${ }^{10} \mathrm{Be}$ samples in the subtropical Andes (20 $-22^{\circ} \mathrm{S}$; Blard et al. [2013]). This new scaling 295 agrees closely (Fig. 3) with new calibration datasets from Patagonia (Kaplan et al., 2011), Peru 296 (Kelley et al., 2015), and New Zealand (Putnam et al., 2010b). All of these calibration data, 
297 individually or compiled (Heyman, 2014), yield lower baseline production rates ( $\sim 3.95 \mathrm{at} / \mathrm{g} / \mathrm{yr}$ )

298 than the older Balco (2008) and Balco et al. (2009) calibrations by $\sim 20 \%$ (although,

299 coincidentally, resulting ages are similar to those given by time-independent Lal/Stone scaling

300 with the Balco (2008) calibration dataset; Fig. 3). Because of the proximity of our field area to

301 the calibration site of Blard et al. (2013), we use this as the basis for our reported ages.

302 Interpreting ages from cosmogenic ${ }^{36} \mathrm{Cl}$ is more complicated than from ${ }^{10} \mathrm{Be}$, because there

303 are multiple production pathways. These include high-energy neutron spallation of $\mathrm{Ca}$ and $\mathrm{K}$,

304 lower-energy epithermal and thermal neutron capture by ${ }^{35} \mathrm{Cl}$, and minor muonogenic

305 production, along with nucleogenic production (Gosse and Phillips, 2001), as opposed to simply

306 neutron spallation and minor muonogenic production of ${ }^{10} \mathrm{Be}$. These production pathways

307 depend on the major and trace elemental chemistry of the samples, including water content to a

308 small degree, and uncertainty in their scaling with latitude and altitude contributes to greater

309 uncertainty, particularly in whole-rock samples as we have used here.

$310 \quad$ Our ${ }^{36} \mathrm{Cl}$ ages were calculated using the Age Calculation Engine (Zweck et al., 2012;

311 http://ace.hwr.arizona.edu) and a time-varying production rate scaling scheme based on latitude-

312 altitude-pressure factors of Stone (2000), sea level curve of Fairbanks (1989) and Shackleton

313 (2000), geomagnetic intensity model of Guyodo and Valet (1999), and paleolatitude record of

314 Ohno and Hamano (1992) and Yang et al. (2000). These choices are consistent with those used

315 by the CRONUS calculator for ${ }^{10} \mathrm{Be}$ and therefore with the other chronologies presented here.

316 Among the available calibration datasets for ${ }^{36} \mathrm{Cl}$ production rates, the Phillips et al. (1996) and

317 Licciardi et al. (2008) datasets produce ${ }^{36} \mathrm{Cl}$ ages most consistent with the ${ }^{10} \mathrm{Be}$ ages of paired

318 samples and samples from the same landform (see Results, section 5, below). Because the low-

319 energy production pathways for ${ }^{36} \mathrm{Cl}$ are generally scaled along with the high-energy pathways 
320 for convenience, yet their scaling is not well-constrained to be the same (e.g., Desilets et al.,

321 2006; Schimmelpfennig et al., 2009), a discussion of which combination of scaling model and

322 calibration dataset is theoretically most appropriate for our study area is beyond the scope of this

323 work. Here, we present the ages based on the scheme that independently gives results best

324 matched overall to the ${ }^{10} \mathrm{Be}$ ages, but do not directly calibrate ${ }^{36} \mathrm{Cl}$ production rates based on our

325 paired samples, because the paired sample set is too small to screen for other random error such

326 as erosion and anomalous histories of sediment cover.

\subsection{Rescaled regional records of past glacial maxima}

329 To take a broad look at spatiotemporal trends in the timing of glaciation in this part of the

330 Andes, we used the CRONUS online calculator to rescale the reported ${ }^{10} \mathrm{Be}$ ages from 16

331 published studies of pre-Holocene tropical and subtropical glacial deposits using a base

332 production rate calibrated based on the same dataset as our Chajnantor chronology, the tropical

333 Andes dataset of Blard et al. (2013) (Table 2). These records were selected by the following

334 criteria: 1) locations between $\sim 10^{\circ}$ and $\sim 30^{\circ} \mathrm{S} ; 2$ ) sufficient published metadata to recalculate

335 exposure ages; and 3) multiple boulder ages reported from one or more moraines. We also

336 include three ${ }^{3} \mathrm{He}$ chronologies, scaled consistently with Blard et al. (2013) as originally

337 published, for a total of 20 records. Each record was examined individually, and outliers that had 338 been excluded by the original authors based on landform context and/or statistical analysis were

339 removed from our dataset. With the exception of our Chajantor record, we also excluded bedrock

340 exposure ages (e.g., from roche moutonnée) from each of these studies that were not

341 immediately adjacent to a moraine deposit; this ensured that intermediate ages associated with

342 retreat between moraine positions were not confused with periods of stillstand or advance. These 
measure were meant to ensure that clusters of ages within each record reflect a consistent

344 measure of the timing of stabilization of a particular moraine deposit.

345 Any combination of multiple published glacial chronologies spanning a large geographical

346 area and published by different workers over the course of a decade is prone to factors that

347 reduce precision relative to the original studies taken in isolation. These may include

348 underconstrained or underreported geological biases related to the specific study sites (e.g.,

349 sample thickness, local constraints on erosion rate, and cosmogenic inheritance), and selective

350 sampling of particular moraines either by study design or because of inadequate sample

351 availability on other moraines. For example, deposits older than LGM are reported but not

352 sampled at many locations, and where they are sampled, older ages are much less precise than

353 younger ones due to scaling uncertainties. Regional atmospheric pressure patterns may also

354 cause variability in production rate scaling between records that is difficult to assess, but may be

355 of order $7-10 \%$ (Farber et al., 2005; Blard et al., 2013). Additionally, prior to revision of the ${ }^{10} \mathrm{Be}$

356 half-life and publication of Nishiizumi et al. (2007), it was not common practice to report AMS

$357{ }^{10} \mathrm{Be} /{ }^{9} \mathrm{Be}$ ratio standardizations in publications, so some chronologies may be prone to a

358 systematic error related to inferring these values in rescaling the data, which could generate

359 artificial misalignment between records (we have noted these cases in the supplemental data

360 tables).

361 Because of these impediments to precision of our merged chronology, we took a broad view

362 and grouped samples from each study that fell within specific time windows: 70-100 ka; 40-70

$363 \mathrm{ka} ; 25-40 \mathrm{ka} ; 20-25 \mathrm{ka}$ (LGM); 15-20 ka (Tauca); and 10-15 ka (late glacial). We did not address

364 the Holocene portions of any of these chronologies. For one of these periods to be counted as a

365 time of moraine stabilization, the central value of at least 3 samples had to fall within in that 
366 period. Periods containing $\leq 2$ samples or samples with high uncertainty relative to others in the

367 dataset were classified as "few/poor ages".

\begin{tabular}{|c|c|c|c|c|c|c|}
\hline $\begin{array}{c}\text { Map } \\
\text { ID }\end{array}$ & Nuclide & Location & $\begin{array}{c}\text { Mean } \\
\text { Latitude } \\
\text { (deg S) }\end{array}$ & $\begin{array}{c}\text { Mean } \\
\text { Longitude } \\
(\text { deg W) }\end{array}$ & $\begin{array}{c}\text { Mean } \\
\text { Elevation } \\
(\mathrm{m})\end{array}$ & Reference \\
\hline 1 & ${ }^{10} \mathrm{Be}$ & Cordillera Blanca, Peru & 9.57 & 77.42 & 3909 & Farber et al., $2005^{\star}$ \\
\hline 2 & ${ }^{10} \mathrm{Be}$ & Cordillera Blanca, Peru & 10.01 & 77.27 & 4321 & Smith and Rodbell, 2010 \\
\hline 3 & ${ }^{10} \mathrm{Be}$ & Cordillera Blanca, Peru & 10.01 & 77.25 & 4391 & Glasser et al., 2009 \\
\hline 4 & ${ }^{10} \mathrm{Be}$ & Cordillera Huayhuash, Peru & 10.23 & 76.89 & 4184 & Hall et al., 2009 \\
\hline 5 & ${ }^{10} \mathrm{Be}$ & Eastern Cordillera, Peru & 11.05 & 75.97 & 4301 & Smith et al., 2005* \\
\hline 6 & ${ }^{10} \mathrm{Be}$ & Cordillera Vilcabamba, Peru & 13.35 & 72.51 & 4330 & Licciardi et al., 2009 \\
\hline 7 & ${ }^{10} \mathrm{Be}$ & Quelccaya, Peru & 13.94 & 70.89 & 4855 & Kelly et al., 2015 \\
\hline 8 & ${ }^{3} \mathrm{He}$ & Nevado Coropuna, Peru & 15.51 & 72.58 & 5074 & Bromley et al., 2009, 2011 \\
\hline 9 & ${ }^{10} \mathrm{Be}$ & Cordillera Real, Bolivia & 15.98 & 68.54 & 4625 & Zech et al., 2007a \\
\hline 10 & ${ }^{10} \mathrm{Be}$ & Cordillera Real, Bolivia & 16.13 & 68.18 & 3675 & Smith et al., 2005* \\
\hline 11 & ${ }^{10} \mathrm{Be}$ & Cordillera Real, Bolivia & 16.26 & 68.11 & 4605 & Jomelli et al., 2011 \\
\hline 12 & ${ }^{10} \mathrm{Be}$ & Cordillera Real, Bolivia & 16.38 & 68.18 & 4604 & Smith et al., $2005^{*}$ \\
\hline 13 & ${ }^{10} \mathrm{Be}$ & Cordillera Real, Bolivia & 16.59 & 67.80 & 4352 & Smith et al., 2011 \\
\hline 14 & ${ }^{10} \mathrm{Be}$ & Cochabamba, Bolivia & 17.22 & 66.36 & 4085 & Zech et al., 2007a \\
\hline 15 & ${ }^{3} \mathrm{He}$ & Cerro Tunupa, Bolivia & 19.87 & 67.61 & 4074 & Blard et al., 2009 \\
\hline 16 & ${ }^{10} \mathrm{Be}$ & Tres Lagunas, Argentina & 22.20 & 65.12 & 4426 & Zech et al., 2009 \\
\hline 17 & ${ }^{3} \mathrm{He}$ & Cerro Uturuncu, Bolivia & 22.31 & 67.20 & 4878 & Blard et al., 2014 \\
\hline 18 & ${ }^{10} \mathrm{Be} /{ }^{36} \mathrm{Cl}$ & Chajnantor Plateau, Chile & 22.91 & 67.80 & 4701 & This study \\
\hline 19 & ${ }^{10} \mathrm{Be}$ & Encierro Valley, Chile & 29.10 & 69.90 & 3902 & Zech et al., 2006 \\
\hline 20 & ${ }^{10} \mathrm{Be}$ & Cordón de Doña Rosa, Chile & 30.71 & 70.40 & 3144 & Zech et al., 2007b \\
\hline
\end{tabular}




\section{5. Results}

\section{5.1. Mapping of glacial features}

375 Our mapping of glacial features at the regional scale (Fig. 3) reveals that approximately 4100

$376 \mathrm{~km}^{2}$ of the $50,000 \mathrm{~km}^{2}$ map area of Fig. 2 was either ice-covered or was encompassed within an

377 ice-covered area. If the ice cover was contemporaneous across the entire map area, then $\sim 10$ -

$37815 \%$ of the land area above $4000 \mathrm{~m}$ was ice-covered at that time. Where they overlap, our map

379 generally agrees with that of Jenny et al., 1996, including the two closely-spaced younger stages

380 and the more distal, poorly preserved older stage or stages of glaciation; we therefore adopt their 381 nomenclature for the Stage I-III moraines.

382 Glacial features on the Chajnantor Plateau include boulder-studded moraines, reaching $10 \mathrm{~m}$ 383 in height and stretching for many tens of $\mathrm{km}$ around the east side of the plateau (Fig. 4). Their 384 counterparts on the western side of the plateau are more subdued, between 2 and $5 \mathrm{~m}$ high, but 385 are also studded with meter-scale boulders. In satellite imagery, these deposits can be traced 386 continuously around the plateau, outlining a former ice cap with a diameter of $\sim 20 \mathrm{~km}$ (Fig. 5).

387 Glacially polished and striated bedrock are common within the moraine boundaries (particularly 388 associated with hard andesite), as are erratics and other large, isolated boulders (Fig. 4).

389 Outlying, more poorly preserved deposits that indicate a prior, more extensive glaciation are also 390 apparent in the field and in the satellite imagery. These are typically broad, low (1-3 m) gravelly 391 deposits with scattered boulders that follow lobate shapes in map view and could be interpreted 392 as degraded moraine fragments.

393 The most prominent (local Stage II) moraines on the Chajnantor Plateau extend to 394 approximately $4600 \mathrm{~m}$ elevation on the eastern side and $4400 \mathrm{~m}$ on the western side of the 395 plateau. The lowest, most distal Stage III moraines mapped reach as low as $\sim 4200 \mathrm{~m}$, on the 
western side of the plateau. On the eastern side, the Stage I moraines appear to be closely nested

397 within the Stage II moraines, separated by $<1 \mathrm{~km}$ (typically by 100-200 m). On the western side,

398 the Stage I moraines are typically farther inboard than the Stage II moraines by $1.5-2 \mathrm{~km}$, up to 5

$399 \mathrm{~km}$ in one outlet valley (Fig. 5).

\section{2. ${ }^{10} \mathrm{Be}$ and ${ }^{36} \mathrm{Cl}$ exposure ages}

402 The $14{ }^{10} \mathrm{Be}$ analyses yielded ages that range from $18 \mathrm{ka}$ to $141 \mathrm{ka}$ (Table 3$)$. Seven of the

$403{ }^{10}$ Be samples yielded ages between 18 and $30 \mathrm{ka}$. Our dataset includes six samples with paired

$404{ }^{10} \mathrm{Be}$ and ${ }^{36} \mathrm{Cl}$ analyses. Using the ACE calculator and scaling scheme choices described above, 405 four of the ${ }^{36} \mathrm{Cl}$ ages on double-dated samples are consistent with the ${ }^{10} \mathrm{Be}$ ages within error and 406 three are nearly identical (Table 3; Fig. 7). Those with the most identically matched ${ }^{10} \mathrm{Be}$ and

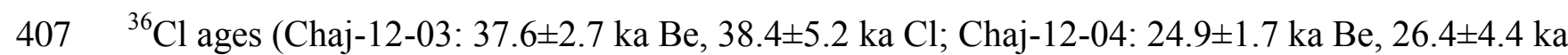
$408 \mathrm{Cl}$ ) are sampled from striated, polished andesitic bedrock, so erosion is known to have been zero 409 over the period of exposure. The two others with well-matched exposure ages are from 410 ignimbritic moraine boulders. The two remaining sets of paired samples yield irreconcilably 411 different ${ }^{36} \mathrm{Cl}$ and ${ }^{10} \mathrm{Be}$ ages; one (Chaj-12-21) has an unreliable ${ }^{10} \mathrm{Be}$ result ( $\sim 50 \%$ analytical 412 uncertainty, and unreasonably high exposure age relative to nearby samples), and the other yields $413 \quad \mathrm{a}^{36} \mathrm{Cl}$ age consistent with other ages from the same moraine, whereas the ${ }^{10} \mathrm{Be}$ age is 414 approximately $10 \%$ as old, again suggesting an unreliable ${ }^{10} \mathrm{Be}$ measurement. We take the ${ }^{36} \mathrm{Cl}$ 415 age as preferred for these two samples.

\subsection{Description of age results and landform associations}

Other ${ }^{36} \mathrm{Cl}$ ages in this dataset generally corroborate the picture painted by the ${ }^{10} \mathrm{Be}$ ages, 419 with bedrock ages falling in proper relative order with ${ }^{10} \mathrm{Be}$ counterparts, and similar moraine 
420 ages on the eastern Chajnantor Plateau (Fig. 5; Table 2). Bedrock ages tend to be clustered in the

421 period 18-30 ka, whereas moraine boulder ages are spread throughout the last $180 \mathrm{ka}$ (Fig. 8).

422 The resulting overall age distribution (both methods) is broad and scattered, with a strong peak at $423 \quad 25 \mathrm{ka}$.

424 Stage I (Fig. 8 A, B): Four Stage I moraine exposure ages range from 19.1-30.1 ka, with 425 one outlying 122 ka boulder. Five of the six exposure ages on bedrock within the Stage I 426 moraines fall between $30 \mathrm{ka}$ and $25 \mathrm{ka}$, in a general progression from oldest near the moraines 427 and younger toward the center of the plateau near the high topography of Cerro Toco and Cerro 428 Chajnantor. Similarly, the bedrock exposure age within the Stage I moraines near Cerro Torta is $42930 \mathrm{ka}$. The $24.6 \mathrm{ka}$ boulder from the moraine near Corro Torta (sample Tat-4) was somewhat 430 degraded and only $\sim 50 \mathrm{~cm}$ tall, and so we regard this as a minimum age; given the consistently 431 older bedrock exposure ages upvalley of the Stage I moraines, we take the 19.1 ka age of sample 432 Chaj-12-20 as also affected by erosion or boulder rotation, and estimate the Stage I moraine 433 abandonment age at $\sim 30 \mathrm{ka}$.

434 Stage II (Fig. 8 C, D): Stage II moraine samples yield four overlapping ages that range

435 from 43.1 to $58.6 \mathrm{ka}$, with two outliers of $89.1 \mathrm{ka}$ and $141 \mathrm{ka}$. Two bedrock samples (Chaj-12-19 436 and Chaj-I3) between the moraines of Stages I and II on the western side of the plateau yield 437 ages of 20.8 and $18.2 \mathrm{ka}$, younger than the more proximal bedrock ages within the Stage I 438 moraines and generally younger than the Stage I moraine samples. These samples were taken 439 from striated bedrock, so erosion of the bedrock itself is negligible here, so we interpret these 440 samples as having been affected by a transient cover of sediment. Our interpreted timing of the 441 Stage II glacial maximum is therefore between $40-60 \mathrm{ka}$, based on the overlapping moraine 442 boulder ages. 
444 of the Chajnantor Plateau yielded an age of $177 \pm 38 \mathrm{ka}$.

\begin{tabular}{|c|c|c|c|c|c|c|c|c|}
\hline Sample & $\begin{array}{c}{ }^{10} \mathrm{Be} \text { Age } \\
\text { (ka) }\end{array}$ & $\begin{array}{c}{ }^{10} \text { Be Uncertainty } \\
\text { (ka) }\end{array}$ & $\begin{array}{l}{ }^{36} \mathrm{Cl} \text { Age } \\
\text { (ka) }\end{array}$ & $\begin{array}{c}{ }^{36} \mathrm{Cl} \text { Uncertainty } \\
\text { (ka) }\end{array}$ & $\begin{array}{l}\text { (M)oraine or } \\
\text { (B)edrock }\end{array}$ & $\begin{array}{l}\text { Local } \\
\text { stage }\end{array}$ & $\begin{array}{c}\text { Preferred } \\
\text { Age (ka) }\end{array}$ & $\begin{array}{c}\text { Pref. Age } \\
\text { Uncertainty } \\
\text { (ka) }\end{array}$ \\
\hline Chaj-12-21 & 91.6 & 47.9 & 14.7 & 1.1 & B & I & 14.7 & 1.1 \\
\hline Chaj-12-04 & 24.9 & 1.7 & 26.4 & 4.4 & B & I & 24.9 & 1.7 \\
\hline Chaj-12-11 & & & 25.7 & 1.7 & B & I & 25.7 & 1.7 \\
\hline Chaj-P2 & 25.9 & 2.2 & & & B & I & 25.9 & 2.2 \\
\hline Chaj-I2 & 30.2 & 2.6 & & & B & I & 30.2 & 2.6 \\
\hline Tat-3 & 30.7 & 2.3 & & & B & I & 30.7 & 2.3 \\
\hline Chaj-12-03 & 37.6 & 2.7 & 38.4 & 5.2 & B & I & 37.6 & 2.7 \\
\hline Chaj-12-19 & 18.2 & 2.8 & 11.2 & 1.3 & B & II & 18.2 & 2.8 \\
\hline Chaj-13 & 20.8 & 1.5 & & & B & II & 20.8 & 1.5 \\
\hline Chaj-12-20 & & & 19.1 & 1.6 & $\mathrm{M}$ & I & 19.1 & 1.6 \\
\hline Tat-4 & 24.6 & 1.8 & & & $M$ & I & 24.6 & 1.8 \\
\hline Chaj-12-15 & & & 30.1 & 2.8 & $\mathrm{M}$ & I & 30.1 & 2.8 \\
\hline Chaj-12-14 & & & 122 & 14.3 & $\mathrm{M}$ & I & 122 & 14.3 \\
\hline Chaj-12-18 & 43.1 & 7 & 40.8 & 3.5 & M & II & 43.1 & 7 \\
\hline Chaj-12-08 & 8.2 & 2.6 & 49 & 13.1 & $M$ & II & 49.0 & 13.1 \\
\hline Chaj-M1 & 50.2 & 3.7 & & & $\mathrm{M}$ & II & 50.2 & 3.7 \\
\hline Chaj-M2 & & & 58.6 & 16.4 & M & II & 58.6 & 16.4 \\
\hline Chaj-M3 & 89.1 & 6.2 & & & $\mathrm{M}$ & II & 89.1 & 6.2 \\
\hline Chaj-M5 & 141 & 9.3 & & & $\mathrm{M}$ & II & 141 & 9.3 \\
\hline Chaj-12-06 & & & 177 & 38 & $\mathrm{M}$ & III & 177 & 38 \\
\hline \multicolumn{9}{|c|}{$\begin{array}{l}\text { 1. All uncertainties include } 1-\sigma \text { analytical uncertainty and propagated production rate scaling uncertainty. } \\
\text { 2. }{ }^{10} \mathrm{Be} \text { scaling: Time-varying Lal/Stone using Blard et al., } 2013 \text { calibration set. }{ }^{36} \mathrm{Cl} \text { scaling: Time-varying Lal/Stone using Phillips, } \\
1996 \text { calibration set. } \\
\text { 3. On paired samples (shaded rows), the }{ }^{10} \mathrm{Be} \text { age is preferred except where inconsistent with landform context and/or exhibits } \\
\text { large measurement uncertainty (struck through records). }\end{array}$} \\
\hline
\end{tabular}

449 To visualize the results of rescaling regional cosmogenic chronologies, we generated

450 probability density (“camel”) plots using all rescaled ages in each record (Fig. 9; high-resolution

451 version provided as supplemental figure S1). These plots are constructed by assuming Gaussian 
452 uncertainty distributions around the central value, and that these distributions represent

453 probability density functions of age; the probability density is binned along the time axis to

454 generate the plot, such that many overlapping samples with slightly different central values

455 generate one merged peak that effectively represents a weighted average (Lowell, 1995). We

456 interpret the timing of peaks in each histogram as indicating moraine formation and stabilization

457 (i.e., glacial maxima and beginning of retreat). Three main periods of moraine formation appear

458 overall (Fig. 9): early LGM (25-40 ka), late LGM/deglacial ( 16-17 ka), and late glacial (10-14

$459 \mathrm{ka})$. In some records, particularly in the tropics, continuous glaciation and multiple stages of

460 moraine formation between the late glacial and LGM are indicated. One important result that

461 emerges from the older ages given by the new cosmogenic scaling is that some moraines

462 previously assigned to the late glacial $(<15 \mathrm{ka})$ are now perhaps better thought of as dating to the

463 Tauca stage ( 16-17 ka), while a separate late glacial (10-13 ka) peak, previously assigned to the

464 early Holocene, appears in many records, especially those in the tropics.

465 To examine spatiotemporal trends, we generated a regional map that includes the

466 locations of the rescaled cosmogenic records (Fig. 10). Each panel shows this map during one of

467 the time windows of interest (70-100 ka; 40-70 ka; $25-40 \mathrm{ka} ; 20-25 \mathrm{ka} ; 15-20 \mathrm{ka}$; and 10-15 ka),

468 and the points representing study locations are colored according to the presence or absence of

469 clustered exposure ages during that period.

470 The maps show that few published records begin before or during the 70-100 ka period.

471 Clustered exposure ages appear across the entire latitude range during the 40-70 ka, 25-40 ka,

472 and 15-20 ka periods, with few ages falling during the 20-25 ka period. A strong 10-15 ka

473 clustering appears as well, but only in areas north of $\sim 20^{\circ} \mathrm{S}$ or on the eastern side of the 
474 Altiplano. Southwest of the Salar de Uyuni area, this younger late glacial period of moraine

475 development is not reported, and it is not in evidence at Chajnantor.

\section{Discussion}

\subsection{Geological sources of uncertainty in Chajnantor exposure ages}

Cosmogenic exposure ages are prone to two competing sources of geological uncertainty:

1) inheritance of inventory from a prior period of exposure, i.e., incomplete resetting by erosion,

481 which increases apparent ages, and 2) postdepositional erosion or transient cover of sediment, 482 tephra, or snow that reduces apparent ages. The scatter among the cosmogenic ages from our 483 study area implies that one or both of these are affecting our results. For example, as described 484 above, the exposure age of the Stage I moraine boulder from Co. Torta is $24.6 \pm 1.8 \mathrm{ka}$, while that 485 of the bedrock sample immediately upvalley is $30.7 \pm 2.3 \mathrm{ka}$ (Fig. 6), which suggests either 486 incomplete resetting of the bedrock sample or postdepositional erosion of the moraine boulder. 487 Because this moraine boulder was only $\sim 50 \mathrm{~cm}$ high and slightly degraded, we take its exposure 488 age to be minimum-limiting and the 30.7 ka bedrock exposure age to more accurately reflect the 489 timing of deglaciation of this valley. Similarly, samples Chaj-12-03 (37.6 ka) and Chaj-12-04

490 (24.9 ka) are within $5 \mathrm{~m}$ of each other on a striated andesitic surface, and so would be expected 491 to yield identical ages. Given that the striations provide evidence for no postdepositional erosion 492 at this location, the older age of Chaj-13-3 is likely to be unreset, again implying shallow and 493 variable bedrock erosion. The difference between these can be accounted for by $\sim 30 \mathrm{~cm}$ of 494 additional erosion (assuming a period of prior exposure of $\sim 70 \mathrm{ka}$ and a rock density of 2.7

$495 \mathrm{~g} / \mathrm{cm}^{3}$ ) at the site of Chaj-12-4. The scatter among moraine ages (Fig. 8) further supports the 496 likely presence of cosmogenic inheritance in many samples. 


\subsection{Interpretation of Chajnantor area glacial history}

499 Our exposure age chronology supports stabilization of Stage II moraines ca. 40-60 ka;

500 continued glaciation until $30 \mathrm{ka}$ or reglaciation at that time (Stage I moraines); and retreat and

501 deglaciation by $25 \mathrm{ka}$ (bedrock exposure in the central plateau). Older Stage III deposits were

502 likely formed prior to $100 \mathrm{ka}$. It is not possible with these data to determine whether the area

503 deglaciated more completely in between Stages II and I, or if the ice cap simply retreated to the

504 Stage I position. However, the relatively small moraines and widespread cosmogenic inheritance

505 suggest limited erosion, perhaps implying that glacial occupations of the plateau were short-

506 lived. Our cosmogenic ages, taken in isolation, suggest deglaciation of the Chajnantor area early

507 in MIS 2 and prior to the global LGM (Fig. 11). We found no evidence of an extensive local

508 glacial advance or stillstand during either the Tauca phase ca. $17 \mathrm{ka}$ or later in the late glacial,

509 implying either that the estimated 3x increase in precipitation in the area at that time (Grosjean et

510 al., 2001) was insufficient or that temperatures were insufficiently cold to generate large glaciers.

\subsection{Chajnantor chronology in the context of regional records}

513 The Chajnantor area appears to have been glaciated during periods of elevated

514 precipitation, as would be expected based on the precipitation sensitivity of modern glaciers in

515 the outer tropics and subtropics (Sagredo et al., 2014). Stage II moraine ages at Chajnantor

516 reasonably align with a period of lake expansion documented in the Salar de Uyuni, on the

517 Bolivan Altiplano, ca. 40-50 ka during Marine Isotope Stage (MIS) 3 or late in MIS 4 (Fig. 11;

518 Baker et al., 2001; Placzek et al., 2013). Similarly, the early LGM glaciation at Chajnantor

519 coincided with moistening periods in the Salar de Atacama and Salar de Uyuni. Curiously, it

520 appears to have deglaciated prior to the wettest (Tauca) phase, 17-14 ka, but this occurred after 
521 global temperatures had increased $\sim 4-6{ }^{\circ} \mathrm{C}$ following the LGM (Denton et al., 2010). The

522 combination of precipitation and temperature conditions needed to glaciate the area may not

523 have been met at that time, despite higher precipitation.

524 The only dated glacial record in our regional synthesis within $\sim 250 \mathrm{~km}$ of Chajnantor is

525 the cosmogenic ${ }^{3} \mathrm{He}$ record at Uturuncu Volcano, Bolivia (Fig. 9; Blard et al., 2014). At both of

526 these sites, moraine ages appear in the $40-70 \mathrm{ka}$ period and near $30 \mathrm{ka}$. A paucity of moraines at

527 Uturuncu during the $\sim 25$ ka period is compatible with the inferred retreat and deglaciation at

528 Chajantor during that time. However, while there is no strong evidence for a 15-20 ka (Tauca)

529 moraine at Chajnantor, there is one at Uturuncu. This might reflect the more proximal position of

530 Uturuncu to Lake Tauca itself, which has been interpreted as a local moisture source supporting

531 glaciation elsewhere in Bolivia (Blard et al., 2009). It may also be a function of altitude; the

532 average elevation of the moraines dated at Uturuncu is nearly $200 \mathrm{~m}$ higher than that at

533 Chajnantor (Table 2), with a different hypsometry ( conical volcanic peak vs. the broad

534 Chajnantor Plateau).

535 Along with our new chronology at Chajnantor, the regional ${ }^{10} \mathrm{Be}$ and ${ }^{3} \mathrm{He}$ glacial

536 chronologies we compiled (Fig. 10) suggest that glaciers between $10^{\circ} \mathrm{S}$ and $30^{\circ} \mathrm{S}$ behaved more

537 or less synchronously before, during, and following the global LGM. Most of these records

538 imply moraine formation during the period 25-40 ka, deglaciation or still-stand during the classic

539 Last Glacial Maximum (20-25 ka), and widespread moraine formation again during 15-20 ka.

540 Glaciers south of $\sim 20^{\circ} \mathrm{S}$ on the western flank of the Andes do not appear to have formed

541 moraines during the late glacial $(10-15 \mathrm{ka})$, while the more tropical glaciers did. The spatial

542 pattern of the late glacial in particular mimics the climate zones of Sagredo and Lowell (2012)

543 (Fig. 10), with the dry outer tropical and southern outer tropical glaciers (Groups 3 and 2.2, 
544 respectively; dominated by easterly, austral summer precipitation) showing a strong late glacial

545 response, but with late glacial deposits not present or unreported in the region of the subtropical

546 glaciers (Group 4; dominated by westerly, austral winter precipitation).

\subsection{Climate drivers of glaciation in the arid Andes}

For the purposes of the following discussion, we interpret periods of moraine formation

550 as minimum-limiting ages on glacial advances. Compared with global climate events, our

551 merged record outlines an early LGM glacial advance, a Heinrich Stadial 1 (HS1) readvance (17-

$55214 \mathrm{ka}$, coinciding with the Tauca highstand of Altiplanic lakes), and a late glacial readvance

553 corresponding either to the Northern Hemisphere Younger Dryas stadial event (YD; 12.9-11.7

$554 \mathrm{ka}$ ) or the Southern Hemisphere Antarctic Cold Reversal (ACR; 14.5-12.8 ka).

Our results support the hypothesis that subtropical South American glaciers are sensitive

556 to Northern Hemisphere drivers. As we described above (section 3.4), recent speleothem work

557 from Peru strongly implies that tropical climates respond to northern hemisphere climate forcing

558 via modulation of the South American Summer Monsoon (SASM; Kanner et al., 2012).

559 Speleothem records from eastern Brazil suggest that the SASM system (including the related

560 Bolivian High) shifts southward during periods of high southern hemisphere insolation (Cruz et

561 al., 2005), due to changes in the position and intensity of latent heating associated with the

562 SASM (Rodwell and Hoskins, 2001; Gandu and Dias, 1998). A corresponding southerly shift in

563 the associated Bolivian High would bring easterly-sourced precipitation to the Altiplano (Fig.

564 1B; Lenters and Cook, 1997; Vuille, 1999). Northern hemisphere glacial fluctuations, including

565 ice sheet expansion and millennial-scale Heinrich events, appear to enhance southerly shifts of 
the SASM and South Atlantic Convergence Zone (Cruz et al., 2006) and weaken the southern

567 Hadley cell and southern subtropical jet (Chiang et al., 2014).

The influence of Atlantic drivers may wane to the southwest across the Andes, with the

569 Southern Westerly Wind belt (SWW) becoming progressively more important as a moisture

570 source. Some enhancement in precipitation to the arid Andes may have been caused by a more

571 northerly position for the SWW at LGM (Maldonado et al., 2005; Rojas et al., 2009); while this

572 was likely not the primary moisture source as far north as Chajnantor, it may have enhanced

573 overall conditions in favor of glaciation. By $\sim 17 \mathrm{ka}$, the SWW was migrating back to the south,

574 returning to approximately its current position by $15 \mathrm{ka} \mathrm{(e.g.,} \mathrm{McCullough} \mathrm{et} \mathrm{al.,} \mathrm{2000;} \mathrm{Rojas} \mathrm{et}$

575 al., 2009; Boex et al., 2013). This is consistent with the shift from winter, westerly precipitation

576 sources to summer, easterly sources documented at Quebrada del Chaco between $17 \mathrm{ka}$ and 11

577 ka by Maldonado et al. (2005). The corresponding loss of the westerly moisture may partly

578 explain the lack of glacial response during the late glacial south of $20^{\circ} \mathrm{S}$ (Fig. 8).

Jomelli et al. (2014) argue based on rescaled cosmogenic chronologies from tropical

580 glacier deposits (some of which were included in this study), and a new ${ }^{10}$ Be record in Colombia, 581 that the largest late glacial advance throughout tropical South America took place not during the 582 YD but during the ACR, a period during which southern mid-high latitude air temperatures (e.g.,

583 Monnin et al., 2001; Williams et al., 2005) and sea-surface temperatures in the Southern Ocean 584 and Pacific Ocean near South America ceased warming or declined slightly (e.g., Lamy et al., 585 2004). Their results suggest a more limited glacial response during the Younger Dryas. Insofar as 586 tropical glaciers are more sensitive than subtropical glaciers to temperature (Sagredo et al., 587 2014), it is conceivable that suppressed sea-surface temperatures during the ACR resulted in a 588 readvance of tropical glaciers but was not combined with sufficient moistening to trigger 
reglaciation of the arid Andes. Other Southern Hemisphere settings that are more sensitive to

590 temperature than precipitation support this mechanism. For example, moraines in New Zealand

591 dated by Putnam et al. (2010a) imply a glacial advance there at the end of the ACR. Most of the

592 South American records do not attain the age precision of either the Jomelli et al. (2014) or the

593 Putnam et al. (2010a) studies, however, and so the end of the ACR and the beginning of the YD

594 would be difficult to distinguish with confidence. Likewise, our merged, rescaled record is

595 insufficiently precise to distinguish between the YD and the ACR. We do note, however, that in

596 eight of the 14 records in our study that show a strong late glacial signal (Fig. 8, 9 - records 1-4,

597 6-14, 16), the late glacial samples cluster more closely within the YD (12.9-11.7 ka) rather than

598 in the ACR (14.5-12.8 ka). Similarly, precise radiocarbon and ${ }^{10}$ Be ages indicate that the

599 Quelccaya Ice Cap (Peru, $13.9^{\circ} \mathrm{S}$ ) retracted during the ACR and advanced during the peak of the

600 YD (12.5-12.35 ka; Kelly et al., 2012, 2015).

601 A potential resolution to these conflicts could be that glaciers in temperature-sensitive

602 locations (e.g., the tropics and Patagonia) readvanced more prominently during the ACR, due to

603 its effect on regional temperatures, whereas those in more precipitation-limited settings

604 readvanced during the YD, which, like HS1, was accompanied by increased easterly moisture

605 supplied to the arid Andes due to Northern Hemisphere modulation of South American

606 circulation (Placzek et al., 2013). Glaciation in the more southern and western arid Andes

607 (between $20^{\circ} \mathrm{S}$ and $\sim 35^{\circ} \mathrm{S}$; e.g., Chajnantor) required a combination of wetter and colder not

608 found after HS1.

609

610 


\section{Conclusions}

We presented the first cosmogenic ${ }^{10} \mathrm{Be}$ and ${ }^{36} \mathrm{Cl}$ exposure ages for glacial features in an

613 arid, presently unglaciated part of the Chilean Andes. The new dates and the mapped glacial

614 features suggest that this region was extensively glaciated prior to or during the global Last

615 Glacial Maximum. Rescaled regional ${ }^{10}$ Be glacial chronologies demonstrate that late Pleistocene

616 wet periods and glaciations were generally synchronous across the dry Andes, with diminishing

617 strength to the southwest across the Altiplano. This spatial pattern implicates easterly moisture in

618 generating sufficient snowfall to glaciate the driest parts of the Andes, while allowing a role for

619 westerly moisture, possibly modulated by the migration of the Southern Westerly Wind belt, in

620 the regions near and south of the Arid Diagonal. Taken in context of the above discussion, our

621 study suggests the hypothesis that the late glacial advance of Andean glaciers in temperature-

622 sensitive locations occurred during the ACR, whereas those in more precipitation-limited settings

623 readvanced during the YD, which like the pre-LGM and HS1, was accompanied by increased

624 easterly moisture to the arid Andes. Glaciation in the arid Andes between $20^{\circ} \mathrm{S}$ and $\sim 35^{\circ} \mathrm{S}$

625 required a combination of wetter and colder not found after HS1. To evaluate this hypothesis will

626 require more precise glacial chronologies to resolve the small time differences between the YD

627 and the ACR, along with detailed examination and precise dating of sparse arid Andes glacial

628 deposits south of $\sim 20^{\circ}$ to confirm whether and to what extent glaciation occurred during the late

629 glacial.

630

631 


\section{Acknowledgments}

The authors would like to thank Marc Caffee, J Radler, and Susan Ma at PRIME Lab for

634 AMS support; Bob Anderson, Miriam Dühnforth, and Kurt Refsnider for logistical support at the

635 University of Colorado Cosmogenic Isotope Lab and Sarah Hammer for support at the

636 University of Cincinnati Cosmogenic Isotope Labs; as well as Kimberly Samuels, Alex Lechler,

637 Chris Sheehan, and the staffs of the Atacama Large Millimeter/Submillimeter Array and the

638 Caltech Chajnantor Test Facility for assistance in the field. We thank Tom Lowell and Andrew

639 Malone for discussion that helped clarify some of the ideas presented here. Funding was

640 provided by the University of New Mexico Research Allocations Committee, the University of

641 New Mexico Latin American and Iberian Institute, and NSF grants EPS-0918635 and EPS-

6420814449 (New Mexico EPSCoR) and EAR-1226611 (Geomorphology and Landuse Dynamics).

643 We thank two anonymous referees for unusually thorough and constructive reviews. 


\section{References}

647

648

649

650

651

652

653

654

655

656

657

658

659

660

661

662

663

664

665

666

Ackert Jr., R.P., Becker, R.A., Singer, B.S., Kurz, M.D., Caffee, M.W., Mickelson, D.M., 2008. Patagonian glacier response during the Late Glacial-Holocene transition. Science 321, 392395.

Amman, C., Jenny, B., Kammer, K., Messerli, B., 2001. Late Quaternary glacier response to humidity changes in the arid Andes of Chile. Palaeogeography, Palaeoclimatology, Palaeoecology, 172, 313-326.

Anderson, L.S., Roe, G.H., Anderson, R.S., 2014. The effects of interannual climate variability on the moraine record. Geology 42, 55-58.

Baker, P.A., Rigsby, C.A., Seltzer, G.O., Fritz, S.C., Lowenstein, T.K., Bacher, N.P., Veliz, C., 2001. Tropical climate changes at millennial and orbital timescales on the Bolivian Altiplano. Nature 409, 698-701.

Baker, P., Fritz, S., 2015. Nature and causes of Quaternary climate variation of tropical South America. Quaternary Science Reviews 124, 31-47.

Balco, G., Stone, J.O., Lifton, N.A., Dunai, T.J., 2008. A complete and easily accessible means of calculating surface exposure ages or erosion rates from $10 \mathrm{Be}$ and $26 \mathrm{Al}$ measurements. Quaternary Geochronology 3, 174-195.

Balco, G., Briner, J., Finkel, R.C., Rayburn, J.A., Ridge, J.C., Schaefer, J.M., 2009. Regional beryllium-10 production rate calibration for northeastern North America. Quaternary Geochronology 4, 93-107. 
Blard, P.-H., Lavé, J., Farley, K.A., Fornari, M., Jiménez, N., Ramirez, V., 2009. Late local

668 glacial maximum in the Central Altiplano triggered by cold and locally-wet conditions during

669 the paleolake Tauca episode (17-15ka, Heinrich 1). Quaternary Science Reviews 28, 3414-

$670 \quad 3427$.

671 Blard, P.H., Braucher, R., Lavé, J., Bourlès, D., 2013. Cosmogenic Be-10 production rate

672 calibrated against He-3 in the high Tropical Andes (3800-4900 m, 20-22 $\mathrm{S})$. Earth and

673 Planetary Science Letters 382, 140-149.

674 Blard, P.-H., Lave, J., Farley, K.A., Ramirez, V., Jimenez, N., Martin, L.C.P., Charreau, J.,

675 Tibari, B., Fornari, M., 2014. Progressive glacial retreat in the Southern Altiplano (Uturuncu

676 volcano, $22^{\circ} \mathrm{S}$ ) between 65 and $14 \mathrm{ka}$ constrained by cosmogenic $3 \mathrm{He}$ dating. Quaternary

$677 \quad$ Research 82, 209-221.

678 Bobst, A.L., Lowenstein, T.K., Jordan, T.E., Godfrey, L.V., Ku, T.L., Luo, S., 2001. A 106 ka

679 paleoclimate record from drill core of the Salar de Atacama, northern Chile.

680 Palaeogeography, Palaeoclimatology, Palaeoecology 173, 21-42.

681 Boex, J., Fogwill, C., Harrison, S., Glasser, N. F., Hein, A., Schnabel, C., Xu, S., 2013. Rapid

682 thinning of the late Pleistocene Patagonian Ice Sheet followed migration of the Southern

683 Westerlies. Scientific reports, 3, doi:10.1038/srep02118.

684 Bromley, G.R.M., Schaefer, J.M., Winckler, G., Hall, B.L., Todd, C.E., Rademaker, K.M., 2009.

685 Relative timing of last glacial maximum and late-glacial events in the central tropical Andes.

686 Quaternary Science Reviews 28, 2514-2526. 
687 Bromley, G.R.M., Hall, B.L., Schaefer, J.M., Winckler, G., Todd, C.E., Rademaker, K.M., 2011.

688 Glacier fluctuations in the southern Peruvian Andes during the late-glacial period,

689 constrained with cosmogenic 3He. Journal of Quaternary Science 26, 37-43.

690 Cesta J., 2015. Timing of alluvial fan development along the Chajnantor Plateau, Atacama

691 Desert, northern Chile: Insights from cosmogenic 36Cl. MS thesis. University of Cincinnati, 692 Cincinnati, OH, USA.

693 Chiang, J. C., Lee, S. Y., Putnam, A. E., Wang, X., 2014. South Pacific Split Jet, ITCZ shifts, 694 and atmospheric North-South linkages during abrupt climate changes of the last glacial 695 period. Earth and Planetary Science Letters 406, 233-246.

696 Cook, K.H., Vizy, E.K., 2006. South American climate during the Last Glacial Maximum:

697 delayed onset of the South American monsoon. J Geophys Res 3, 1-21.

698 Cook, K. H., 2009. South American climate variability and change: remote and regional forcing 699 processes. In Past Climate Variability in South America and Surrounding Regions, 193-212. $700 \quad$ Springer Netherlands.

701 Cruz, F.W., Burns, S.J., Karmann, I., Sharp, W.D., Vuille, M., Cardoso, A.O., Ferrari, J.A., Dias, 702 P.L.S., Viana, O., 2005. Insolation-driven changes in atmospheric circulation over the past $703 \quad 116,000$ years in subtropical Brazil. Nature 434, 63-66.

704 Cruz, F.W., Burns, S.J., Karmann, I., Sharp, W.D., Vuille, M., 2006. Reconstruction of regional 705 atmospheric circulation features during the late Pleistocene in subtropical Brazil from oxygen 706 isotope composition of speleothems. Earth and Planetary Science Letters 248, 495-507.

707 De Martonne, E., 1934. The Andes of the North-West Argentine. Geographical Journal, 1-14. 
Denton, G.H., Anderson, R.F., Toggweiler, J.R., Edwards, R.L., Schaefer, J.M., Putnam, A.E., 709 2010. The last glacial termination. Science 328, 1652-1656.

710 Desilets, D., Zreda, M., 2003. Spatial and temporal distribution of secondary cosmic-ray nucleon 711 intensities and applications to in situ cosmogenic dating. Earth and Planetary Science Letters $712 \quad 206,21-42$.

713 Desilets, D., Zreda, M., Prabu, T., 2006. Extended scaling factors for in situ cosmogenic 714 nuclides: New measurements at low latitude. Earth and Planetary Science Letters 246, 265 715276.

716 Dunai, T.J., 2001. Influence of secular variation of the geomagnetic field on production rates of 717 in situ produced cosmogenic nuclides. Earth and Planetary Science Letters 193, 197-212.

718 Fairbanks, R.G., 1989. A 17,000 year glacio-eustatic sea level record: influence of glacial 719 melting rates on the Younger Dryas event and deep ocean circulation. Nature 342, 637-642.

720 Farber, D., Hancock, G., Finkel, R., Rodbell, D., 2005. The age and extent of tropical alpine 721 glaciation in the Cordillera Blanca, Peru. Journal of Quaternary Science 20, 7- 8, 759-776, 722 doi: $10.1002 /$ jqs.994.

723 Farr, T. G., Rosen, P. A., Caro, E., Crippen, R., Duren, R., Hensley, S., Kobrick, M., Paller, M. 724 Rodrigez, E., Roth, L., Seal, D., Shaffer, S., Shimada, J., Umalnd, J., Werner, M., Oskin., M., 725 Burbank, D., Alsdorf, D., 2007. The shuttle radar topography mission. Reviews of 726 geophysics 45.

727 Gandu, A.W., Dias, P.L.S., 1998. Impact of tropical heat sources on the South American 728 tropospheric upper circulation and subsidence. Journal of Geophysical Research 103, 60017296015. 
730 Garreaud, R.D., 2000. Intraseasonal variability of moisture and rainfall over the South American $731 \quad$ Altiplano. Monthly Weather Review 128, 3337-3346.

732 Garreaud, R.D., Aceituno, P., 2001. Interannual rainfall variability over the South American 733 Altiplano. Journal of Climate 14, 2779-2789.

734 Gayo, E. M., Latorre, C., Jordan, T. E., Nester, P. L., Estay, S. A., Ojeda, K. F., Santoro, C. M., 735 2012. Late Quaternary hydrological and ecological changes in the hyperarid core of the 736 northern Atacama Desert ( 21 S). Earth-Science Reviews 113, 120-140.

737 Glasser, N. F., Clemmens, S., Schnabel, C., Fenton, C. R., McHargue, L., 2009. Tropical glacier 738 fluctuations in the Cordillera Blanca, Peru between 12.5 and $7.6 \mathrm{ka}$ from cosmogenic $10 \mathrm{Be}$ 739 dating. Quaternary Science Reviews 28, 3448-3458.

740 Gosse, J.C., Phillips, F.M., 2001. Terrestrial in situ cosmogenic nuclides: theory and application. 741 Quaternary Science Reviews 20, 1475-1560.

742 Graf, K., 1991. Ein Modell zur eiszeitlichen und heutigen Vergletscherung in der bolivianischen 743 Westkordillere. Bamberger Geographische Schriften 11, 139-154.

744 Grenon, M., 2007. Nature Around the ALMA Site-Part 1. ESO: The Messenger 59-63.

745 Grosjean, M., Van, L., JFN, Van, D.K., WO, Geyh, M.A., Ammann, B., Tanner, W., Messerli, 746 B., Valero-Garcés, B.L., Veit, H., 2001. A 22,000 14C year BP sediment and pollen record of 747 climate change from Laguna Miscanti (23 S), northern Chile. Global and Planetary Change $748 \quad 28,35-51$.

749 Guyodo, Y., Valet, J.-P., 1999. Global changes in intensity of the earth's magnetic field during 750 the past $800 \mathrm{kyr}$. Nature $399,249-252$. 
751 Hall, S. R., Farber, D. L., Ramage, J. M., Rodbell, D. T., Finkel, R. C., Smith, J. A., Mark, B.G.

752 Kassel, C., 2009. Geochronology of Quaternary glaciations from the tropical Cordillera

753 Huayhuash, Peru. Quaternary Science Reviews 28, 2991-3009.

754 Hartley, A.J., 2003. Andean uplift and climate change. Journal of the Geological Society 160, 7$755 \quad 10$.

756 Heyman, J., 2014. Paleoglaciation of the Tibetan Plateau and surrounding mountains based on 757 exposure ages and ELA depression estimates. Quaternary Science Reviews 91, 30-41.

758 Houston, J., 2006, Variability of precipitation in the Atacama Desert: its causes and hydrological 759 impact. International Journal of Climatology 26, 2181-2198.

760 Jenny, B., Kammer, K., Ammann, C., 1996. Climate change in den trockenen Anden. Verlag des 761 Geographischen Institutes der Universität Bern.

762 Jomelli, V., Favier, V., Vuille, M., Braucher, R., Martin, L., Blard, P.-H., Colose, C., Brunstein,

763 D., He, F., Khodri, M., 2014. A major advance of tropical Andean glaciers during the

764 Antarctic cold reversal. Nature 513, 224-228.

765 Jomelli, V., Khodri, M., Favier, V., Brunstein, D., Ledru, M.-P., Wagnon, P., Blard, P.-H., 766 Sicart, J.-E., Braucher, R., Grancher, D., 2011. Irregular tropical glacier retreat over the 767 Holocene epoch driven by progressive warming. Nature 474, 196-199.

768 Kanner, L. C., Burns, S. J., Cheng, H., Edwards, R. L., 2012. High-latitude forcing of the South 769 American summer monsoon during the last glacial. Science 335, 570-573. 
770 Kaplan, M.R., Strelin, J.A., Schaefer, J.M., Denton, G.H., Finkel, R.C., Schwartz, R., Putnam,

771 A.E., Vandergoes, M.J., Goehring, B.M., Travis, S.G., 2011. In-situ cosmogenic 10 Be

772 production rate at Lago Argentino, Patagonia: Implications for late-glacial climate

773 chronology. Earth and Planetary Science Letters 309, 21-32.

774 Kaplan, M., Moreno, P., Rojas, M., 2008. Glacial dynamics in southernmost South America

775 during Marine Isotope Stage 5e to the Younger Dryas chron: a brief review with a focus on

776 cosmogenic nuclide measurements, J. Quaternary Sci. 23, 649-658, doi:10.1002/jqs.1209.

777 Kelly, M., Lowell, T., Applegate, P., Smith, C., Phillips, F., Hudson, A., 2012. Late glacial

778 fluctuations of Quelccaya Ice Cap, southeastern Peru. Geology 40, 991-994, doi:

$779 \quad 10.1130 / \mathrm{G} 33430.1$.

780 Kelly, M.A., Lowell, T.V., Applegate, P.J., Phillips, F.M., Schaefer, J.M., Smith, C.A., Kim, H., 781 Leonard, K.C., Hudson, A.M., 2015. A locally calibrated, late glacial Be-10 production rate 782 from a low-latitude, high-altitude site in the Peruvian Andes. Quaternary Geochronology, 26, $783 \quad 70-85$

784 Kohl, C. P., Nishiizumi, K., 1992. Chemical isolation of quartz for measurement of in-situ785 produced cosmogenic nuclides. Geochimica et Cosmochimica Acta 56, 3583-3587.

786 Kull, C., Grosjean, M., 2000. Late Pleistocene climate conditions in the north Chilean Andes 787 drawn from a climate--glacier model. Journal of Glaciology 46, 622-632.

788 Lal, D., 1991. Cosmic ray labeling of erosion surfaces: in situ nuclide production rates and 789 erosion models. Earth and Planetary Science Letters 104, 424-439. 
Lamy, F., Kaiser, J., Ninnemann, U., Hebbeln, D., Arz, H.W., Stoner, J., 2004. Antarctic timing 791 of surface water changes off Chile and Patagonian ice sheet response. Science 304, 19597921962.

793 Latorre, C., Betancourt, J.L., Arroyo, M.T.K., 2006. Late Quaternary vegetation and climate 794 history of a perennial river canyon in the Rio Salado basin (22 S) of Northern Chile. 795 Quaternary Research 65, 450-466.

796 Lenters, J.D., Cook, K.H., 1997. On the origin of the Bolivian high and related circulation 797 features of the South American climate. Journal of the Atmospheric Sciences 54, 656-678.

798 Licciardi, J.M., Denoncourt, C.L., Finkel, R.C., 2008. Cosmogenic $36 \mathrm{Cl}$ production rates from 799 Ca spallation in Iceland. Earth and Planetary Science Letters 267, 365-377.

800 Licciardi, J. M., Schaefer, J. M., Taggart, J. R., Lund, D. C., 2009. Holocene glacier fluctuations 801 in the Peruvian Andes indicate northern climate linkages. Science, 325, 1677-1679.

802 Lifton, N.A., Bieber, J.W., Clem, J.M., Duldig, M.L., Evenson, P., Humble, J.E., Pyle, R., 2005. 803 Addressing solar modulation and long-term uncertainties in scaling secondary cosmic rays 804 for in situ cosmogenic nuclide applications. Earth and Planetary Science Letters 239, 140$805 \quad 161$.

806 Lifton, N., Sato, T., Dunai, T.J., 2014. Scaling in situ cosmogenic nuclide production rates using 807 analytical approximations to atmospheric cosmic-ray fluxes. Earth and Planetary Science $808 \quad$ Letters $386,149-160$.

809 Lisiecki, L. E., Raymo, M. E., 2005. A Pliocene- Pleistocene stack of 57 globally distributed 810 benthic $\delta 180$ records. Paleoceanography 20. 
811 Lowell, T.V., 1995. The application of radiocarbon age estimates to the dating of glacial 812 sequences: an example from the Miami sublobe, Ohio, USA. Quaternary Science Reviews $813 \quad 14,85-99$.

814 Maldonado, A., Betancourt, J. L., Latorre, C., Villagran, C., 2005. Pollen analyses from a 815 50000- yr rodent midden series in the southern Atacama Desert $\left(25^{\circ} 30^{\prime} \mathrm{S}\right)$. Journal of 816 Quaternary Science, 20, 493-507.

817 Mather, A.E., Hartley, A., 2005. Flow events on a hyper-arid alluvial fan: Quebrada Tambores, 818 Salar de Atacama, northern Chile. Special Publication-Geological Society of London 251, 9.

819 McCulloch, R. D., Bentley, M. J., Purves, R. S., Hulton, N. R. J., Sugden, D. E., Clapperton, C. 820 M., 2000. Climatic inferences from glacial and palaeoecological evidence at the last glacial 821 termination, southern South America. Journal of Quaternary Science 15, 409-417.

822 Monnin, E., Indermühle, A., Dällenbach, A., Flückiger, J., Stauffer, B., Stocker, T.F., Raynaud, 823 D., Barnola, J.-M., 2001. Atmospheric CO2 concentrations over the last glacial termination. $824 \quad$ Science 291, 112-114.

825 Moreno, P. I., M. R. Kaplan, J. P. François, Villa-Martínez, C. M. Moy, C. R. Stern, P. W.

826 Kubik, 2009. Renewed glacial activity during the Antarctic cold reversal and persistence of 827 cold conditions until 11.5 ka in southwestern Patagonia. Geology 37, 375-378, 828 doi:10.1130/G25399A.1.

829 Nishiizumi, K., Elmore, D., Ma, X. Z., Arnold, J. R., 1984. 10 Be and $36 \mathrm{Cl}$ depth profiles in an $830 \quad$ Apollo 15 drill core. Earth and Planetary Science Letters 70, 157-163. 
831 Nishiizumi, K., Imamura, M., Caffee, M.W., Southon, J.R., Finkel, R.C., McAninch, J., 2007.

832 Absolute calibration of 10 Be AMS standards. Nuclear Instruments and Methods in Physics

833 Research Section B: Beam Interactions with Materials and Atoms 258, 403-413.

834 Ohno, M., Hamano, Y., 1992. Geomagnetic poles over the past 10,000 years. Geophysical

$835 \quad$ Research Letters 19, 1715-1718.

836 Phillips, F.M., Zreda, M.G., Flinsch, M.R., Elmore, D., Sharma, P., 1996. A reevaluation of

837 cosmogenic $36 \mathrm{Cl}$ production rates in terrestrial rocks. Geophysical Research Letters $23,949-$

838952.

839 Placzek, C. J., Quade, J., Patchett, P. J., 2013. A 130ka reconstruction of rainfall on the Bolivian

$840 \quad$ Altiplano. Earth and Planetary Science Letters 363, 97-108.

841 Putnam, A.E., Denton, G.H., Schaefer, J.M., Barrell, D.J.A., Andersen, B.G., Finkel, R.C.,

842 Schwartz, R., Doughty, A.M., Kaplan, M.R., Schlüchter, C., 2010a. Glacier advance in

843 southern middle-latitudes during the Antarctic Cold Reversal. Nature Geoscience 3, 700-704.

844 Putnam, A.E., Schaefer, J.M., Barrell, D.J.A., Vandergoes, M., Denton, G.H., Kaplan, M.R.,

845 Finkel, R.C., Schwartz, R., Goehring, B.M., Kelley, S.E., 2010b. In situ cosmogenic 10 Be

846 production-rate calibration from the Southern Alps, New Zealand. Quaternary

$847 \quad$ Geochronology 5, 392-409.

848 Quade, J., Rech, J.A., Betancourt, J.L., Latorre, C., Quade, B., Rylander, K.A., Fisher, T., 2008.

849 Paleowetlands and regional climate change in the central Atacama Desert, northern Chile.

850 Quaternary Research 69, 343-360.

851 Ramírez, C.F., Gardeweg, M., 1982. Hoja Toconau, Región de Antofagasta: Carta Geológica de

852 Chile, 1:250,000. Servicio Nacional de Geología y Minería de Chile, Boletin 54 
853 Raymo, M. E., Oppo, D. W., Curry, W., 1997. The mid- Pleistocene climate transition: A deep

854 sea carbon isotopic perspective. Paleoceanography 12, 546-559.

855 Rech, J.A., Quade, J., Betancourt, J.L., 2002. Late Quaternary paleohydrology of the central

856 Atacama Desert (lat 22--24 S), Chile. Geological Society of America Bulletin 114, 334.

857 Risacher, F., Fritz, B., 2009. Origin of salts and brine evolution of Bolivian and Chilean salars.

$858 \quad$ Aquatic Geochemistry 15, 123-157.

859 Rodbell, D., Smith, J., Mark, B., 2009. Glaciation in the Andes during the Lateglacial and

860 Holocene. Quaternary Science Reviews 28, 2165-2212.

861 Rodwell, M.R., Hoskins, B.J., 2001. Subtropical anticyclones and monsoons. J. Climate 14, $862 \quad 3192-3211$.

863 Roe, G.H., O’Neal, M.A., 2009. The response of glaciers to intrinsic climate variability:

864 observations and models of late-Holocene variations in the Pacific Northwest. Journal of

$865 \quad$ Glaciology 55, 839-854.

866 Rojas, M., Moreno, P., Kageyama, M., Crucifix, M., Hewitt, C., Abe-Ouchi, A., Ohgaito, R.,

867 Brady, E.C., Hope, P., 2009. The Southern Westerlies during the last glacial maximum in

868 PMIP2 simulations. Climate Dynamics 32, 525-548.

869 Sagredo, E.A., Lowell, T.V., 2012. Climatology of Andean glaciers: A framework to understand

870 glacier response to climate change. Global and Planetary Change 86, 101-109.

871 Sagredo, E.A., Rupper, S., Lowell, T.V., 2014. Sensitivities of the equilibrium line altitude to 872 temperature and precipitation changes along the Andes. Quaternary Research 81, 355-366. 
873 Sato, T., Yasuda, H., Niita, K., Endo, A., Sihver, L., Lifton, N.A., 2008. Development of

874 PARMA: PHITS-based analytical radiation model in the atmosphere. Radiation research 170, $875 \quad 244-259-03$.

876 Schmitt, A., de, S., S., Trumbull, R., Emmermann, R., 2001. Magma evolution in the Purico 877 ignimbrite complex, northern Chile: evidence for zoning of a dacitic magma by injection of 878 rhyolitic melts following mafic recharge. Contributions to Mineralogy and Petrology 140, $879 \quad 680-700$.

880 Schimmelpfennig, I., Benedetti, L., Finkel, R., Pik, R., Blard, P. H., Bourles, D., Burnard, P., 881 Williams, A., 2009. Sources of in-situ $36 \mathrm{Cl}$ in basaltic rocks. Implications for calibration of 882 production rates. Quaternary Geochronology 4, 441-461.

883 Shackleton, N.J., 2000. The 100,000-year ice-age cycle identified and found to lag temperature, 884 carbon dioxide, and orbital eccentricity. Science 289, 1897-1902.

885 Smith, J. A., Seltzer, G. O., Farber, D. L., Rodbell, D. T., Finkel, R. C., 2005. Early local last 886 glacial maximum in the tropical Andes. Science 308, 678-681.

887 Smith, J. A., Mark, B. G., Rodbell, D. T., 2008. The timing and magnitude of mountain 888 glaciation in the tropical Andes. Journal of Quaternary Science 23, 609-634.

889 Smith, J. A., Rodbell, D. T., 2010. Cross- cutting moraines reveal evidence for North Atlantic 890 influence on glaciers in the tropical Andes. Journal of Quaternary Science 25, 243-248.

891 Smith, C. A., Lowell, T. V., Owen, L. A., Caffee, M. W., 2011. Late Quaternary glacial 892 chronology on Nevado Illimani, Bolivia, and the implications for paleoclimatic 893 reconstructions across the Andes. Quaternary Research 75, 1-10. 
894 Stone, J. O., 2000. Air pressure and cosmogenic isotope production. Journal of Geophysical 895 Research: Solid Earth, 105(B10), 23753-23759.

896 Stone, J. O., Allan, G. L., Fifield, L. K., Cresswell, R. G., 1996. Cosmogenic chlorine-36 from 897 calcium spallation. Geochimica et Cosmochimica Acta, 60, 679-692.

898 Svensson, A., Andersen, K.K., Bigler, M., Clausen, H.B., Dahl-Jensen, D., Davies, S.M., 899 Johnsen, S.J., Muscheler, R., Parrenin, F., Rasmussen, S.O., 2008. A 60000 year Greenland $900 \quad$ stratigraphic ice core chronology. Climate of the Past 4, 47-57.

901 Sylvestre, F., Servant, M., Servant-Vildary, S., Causse, C., Fournier, M., Ybert, J.-P., 1999.

902 Lake-level chronology on the Southern Bolivian Altiplano (18-23 S) during late-glacial time 903 and the early Holocene. Quaternary Research 51, 54-66.

904 Vuille, M., 1999. Atmospheric circulation over the Bolivian Altiplano during dry and wet 905 periods and extreme phases of the Southern Oscillation. International Journal of Climatology $906 \quad 19,1579-1600$.

907 Vuille, M., Hardy, D.R., Braun, C., Keimig, F., Bradley, R.S., 1998. Atmospheric circulation 908 anomalies associated with 1996/1997 summer precipitation events on Sajama Ice Cap, 909 Bolivia. Journal of Geophysical Research 103, 11191.

910 Ward, D.J., Anderson, R.S., Guido, Z.S., Briner, J.P., 2009. Numerical modeling of cosmogenic 911 deglaciation records, Front Range and San Juan mountains, Colorado. Journal of Geophysical $912 \quad$ Research 114, F01026.

913 Wang, X., Auler, A.S., Edwards, R.L., Cheng, H., Ito, E., Solheid, M., 2006. Interhemispheric 914 anti-phasing of rainfall during the last glacial period. Quaternary Science Reviews 25, 33919153403. 
916 Wang, X., Auler, A.S., Edwards, R.L., Cheng, H., Ito, E., Wang, Y., Kong, X., Solheid, M.,

917 2007. Millennial, Äêscale precipitation changes in southern Brazil over the past 90,000 years.

918 Geophysical Research Letters 34.

919 Williams, P.W., King, D.N.T., Zhao, J.-X., Collerson, K.D., 2005. Late Pleistocene to Holocene 920 composite speleothem 180 and 13C chronologies from South Island, New Zealand—Did a

921 global Younger Dryas really exist? Earth and Planetary Science Letters 230, 301-317, doi:

$922 \quad$ 10.1016/j.eps1.2004.10.024.

923 Yang, S., Odah, H., Shaw, J., 2000. Variations in the geomagnetic dipole moment over the last

92412000 years. Geophysical Journal International 140, 158-162.

925 Zech, R., Kull, C., Veit, H., 2006. Late Quaternary glacial history in the Encierro Valley,

926 northern Chile $\left(29^{\circ} \mathrm{S}\right)$, deduced from $10 \mathrm{Be}$ surface exposure dating. Palaeogeography,

927 Palaeoclimatology, Palaeoecology 234, 277-286, doi: 10.1016/j.palaeo.2005.10.011.

928 Zech, R., Kull, C., Kubik, P. W., Veit, H., 2007a. LGM and Late Glacial glacier advances in the

929 Cordillera Real and Cochabamba (Bolivia) deduced from 10 Be surface exposure dating.

930 Climate of the Past Discussions 3, 839-869.

931 Zech, R, Kull, C., Kubik, PW, Veit, H, 2007b. Exposure dating of Late Glacial and pre-LGM

932 moraines in the Cordon de Doña Rosa, Northern/Central Chile $\left(\sim 31^{\circ} \mathrm{S}\right)$. Climate of the Past

933 3, 1-14, doi: 10.5194/cp-3-1-2007.

934 Zech, R., May, J.H., Kull, C., Ilgner, J., Kubik, P.W., Veit, H., 2008. Timing of the late

935 Quaternary glaciation in the Andes from $\sim 15$ to $40^{\circ} \mathrm{S}$. Journal of Quaternary Science 23, $936 \quad 635-647$. 
937 Zech, J., Zech, R., Kubik, P. W., Veit, H., 2009. Glacier and climate reconstruction at Tres

938 Lagunas, NW Argentina, based on 10 Be surface exposure dating and lake sediment

939 analyses. Palaeogeography, Palaeoclimatology, Palaeoecology 284, 180-190.

940 Zweck, C., Zreda, M., Anderson, K., Bradley, E., 2012. The theoretical basis of ACE, an Age

941 Calculation Engine for cosmogenic nuclides. Chemical Geology 291, 199-205, doi:

$942 \quad 10.1016 /$ j.chemgeo.2011.10.005.

943 
946 Fig. 1. A: Location map of the study area in the subtropical Andes. Red dashed box indicates

947 extent of Fig. 2; CP: Chajnantor Plateau. B: Modern climate features of South America. BH:

948 Bolivian High; SASM: South American Summer Monsoon; ITCZ - Intertropical Convergence

949 Zone (mean northern and southernmost annual positions after Cook et al., 2009 and Baker and

950 Fritz, 2015). Chajnantor area is marked with a star. Glacial climate zones (colored areas)

951 numbered as in Sagredo and Lowell (2012) and dominant sensitivity generalized from Sagredo et

952 al. (2014): 1.1: Inner tropics (temperature-sensitive glaciers); 2.1, 2.2, and 3: Northern, southern,

953 and dry outer tropics (precipitation- and temperature-sensitive); 4 and 5: Subtropics and northern

954 mid-latitudes (precipitation-sensitive); 6.1, 6.2, and 7: Patagonia (temperature-sensitive); 1.2:

955 Tierra del Fuego (precipitation- and temperature-sensitive).

Fig. 2. Regional distribution of moraines and drift limits (red lines). Chajnantor area shown in 958 detail in Fig. 4; Co. Torta area is shown in Fig. 5.

Fig. 3. Age differences for a typical sample due to different production rate calibration datasets relevant to the central Andes. The new calibrations differ by $<7 \%$ across the relevant time range, similar to the $\sim 5-10 \%$ analytical error on most ${ }^{10}$ Be measurements. The Blard et al. (2013)

963 calibration used in this study falls in the middle of the range of new calibrations.

965 Fig. 4. Field evidence for glaciation of the Chajnantor Plateau area. A: Polished, striated andesite 966 near Co. Toco; dark erratic boulder is $\sim 30 \mathrm{~cm}$ in diameter. B: Stage II moraine (low ridge in 967 middle ground, $100 \mathrm{~m}$ behind the large boulder) on the west edge of the plateau below Co. 968 Negro. Backpack circled for scale. C: Nested 10-m-high Stage II and III moraines on the east 969 side of the plateau. D: Stage I terminal and lateral moraines of the valley glacier near Co. Torta, $970 \quad$ 10-15 m high.

972 Fig. 5. Geomorphic and topographic map of the Chajnantor Plateau area. Topographic contours 973 and hillshade are based on the 8-m DigitalGlobe DEM. Exposure ages (ka) as described below 974 (black: ${ }^{10} \mathrm{Be}$, gray: ${ }^{36} \mathrm{Cl}$ ). 
976 Fig. 6. Co. Torta area Landsat image with sketch map of moraine ridges and locations of ${ }^{10} \mathrm{Be}$ 977 exposure ages. The moraine boulder was relatively small $(<50 \mathrm{~cm})$ and weathered, so is taken as 978 a minimum-limiting age.

980 Fig. 7. A: Correspondence between ${ }^{10} \mathrm{Be}$ and ${ }^{36} \mathrm{Cl}$ exposure ages of paired samples using a time981 varying Lal/Stone scaling and the Phillips (1996) calibration dataset. Hollow symbols indicate 982 samples $>2-\sigma$ from the 1:1 line. B: Exposure ages for the four most reliable paired samples 983 using different production rate calibration datasets for ${ }^{36} \mathrm{Cl}$. Error bars omitted for clarity. For our 984 field area, the calibrations of Phillips et al. (1996) and Licciardi et al. (2008) yield the same ages 985 within a few hundred years, with differences $<<$ uncertainty; the Swanson and Caffee (2001) 986 calibration dataset gives ages lower by $\sim 12 \%$, but still within $2-\sigma$ uncertainty. We use the 987 Phillips (1996) calibration for ages reported in this work.

989 Fig. 8. Relative probability of cosmogenic ages given their respective uncertainties, separated 990 into moraine boulder and bedrock samples, using the preferred exposure age for each sample as 991 in Table 3. Note the time scale change between the moraine and bedrock panels. Shaded bands 992 are our interpreted age ranges for each feature. See text for discussion.

994 Figure 9. Probability density plots from each rescaled study (numbered as in Table 2) with 995 periods from Fig. 9 highlighted. For a period to be counted as a time of moraine stabilization, at 996 least 3 samples had to form a peak or sub-peak in that period; periods containing $\leq 2$ samples or 997 samples with high uncertainty relative to others in the dataset were classified as "few/poor ages" 998 in Fig. 10. A high-resolution version of this figure with expanded time axes is provided as 999 Supplemental Fig. S1. 
1002 Fig. 11: Bedrock and moraine boulder ${ }^{10} \mathrm{Be}$ and ${ }^{36} \mathrm{Cl}$ ages from the Chajnantor Plateau. Hollow 1003 circles represent ages that may be excluded based on landform context. Sedimentary hydrologic 1004 proxy records from Salar de Atacama (Bobst et al., 2001) and Salar de Uyuni (Baker et al., 1005 2001). NGRIP ice core $\delta^{18} \mathrm{O}$ record from Svensson et al., 2008. Globally distributed benthic $\delta^{18} \mathrm{O}$ 1006 records of Lisiecki and Raymo (2005), black, and regional benthic $\delta^{18} \mathrm{O}$ from IODP core 677 off 1007 the Peruvian coast as described in Raymo et al. (1997), red.

1008

1009

1010 
1011 Appendix 1. Laboratory methods and full sample data tables

1012

1013 A1.1. Sample preparation $-{ }^{10} \mathrm{Be}$

1014 The procedures to purify quartz from rock samples were modified after that of Kohl and

1015 Nishiizumi (1992), and the chemical preparation of AMS targets was based on the procedures of

1016 Nishiizumi et al. (1984) as modified for the University of Colorado and University of Cincinnati

1017 cosmogenic isotope labs. In general, approximately $1 \mathrm{~kg}$ of each sample was crushed and sieved

1018 to the $350-850 \mu$ fraction, 100 grams of which were processed by heavy liquids separation and

1019 leaching by dilute $\mathrm{HCl}$ and $\mathrm{HF} / \mathrm{HNO}_{3}$ to yield pure quartz. $0.6-10 \mathrm{~g}$ aliquots of quartz were

1020 spiked with $\sim 0.25 \mathrm{mg}$ of SPEX CLBE2-2Y ${ }^{9}$ Be carrier, then dissolved in concentrated HF.

1021 Dissolved samples were dried and treated with $\mathrm{HClO}_{4}$ to remove excess fluorine, then eluted

1022 through low-pressure anion and cation exchange columns to separate Be from B, Ti, Fe, and

1023 other interfering ions. Ti was also selectively removed by $\mathrm{HCl}-\mathrm{HNO}_{3}$ titration to $\mathrm{pH} 4-5$. Be

1024 hydroxide was precipitated using $\mathrm{HCL}-\mathrm{HNO}_{3}$ titration to $\mathrm{pH} 8$, then transferred to quartz

1025 crucibles and oxidized in a muffle furnace. The Be oxide was packed with $\mathrm{Nb}$ powder into

1026 cathode sample holders for the AMS at Purdue Rare Isotope Measurement (PRIME) Lab, where

$1027{ }^{10} \mathrm{Be} /{ }^{9} \mathrm{Be}$ ratios were determined. From these ratios concentrations of ${ }^{10} \mathrm{Be}$ were calculated for the 1028 original quartz samples.

1029

1030 A1.2. Sample preparation $-{ }^{36} \mathrm{Cl}$

1031 Extraction, chemical preparation, and sample dissolution for chlorine followed the

1032 procedures of Stone et. al. (1996b). Procedures were slightly modified to accelerate the 
1033 dissolution process (Radler, pers. comm.) and are outlined here. Samples were pulverized in a 1034 jaw crusher and sieved to $125-250 \mu \mathrm{m}$. Densities were determined on representative sample 1035 pieces, $\sim 2 \mathrm{~cm}$ diameter, using Archimedes principle. Two $\sim 10 \mathrm{~g}$ aliquots of the $125-250 \mu \mathrm{m}$ 1036 sieved whole rock fraction were retained for bulk rock geochemistry. Major and trace element 1037 compositions were analyzed by ICP-MS at Activation Laboratories Ltd in Ontario, Canada. 1038 Approximately $80 \mathrm{~g}$ of the sieved fraction for each sample was leached overnight (12-16 hr.) in $103970 \% \mathrm{HNO}_{3}(2 \mathrm{M})$ to remove contaminants and eliminate the meteoric ${ }^{36} \mathrm{Cl}$ component. The 1040 remaining solids were rinsed five times with $18 \mathrm{M} \Omega \mathrm{H}_{2} \mathrm{O}$ to remove the fines and dried overnight 1041 (12-16 hr.) at $85^{\circ} \mathrm{C}$. After drying, roughly $30 \mathrm{~g}$ of the leached material was dissolved in a $40 \%$ 1042 Low Chloride $\mathrm{HF} / 70 \% \mathrm{HNO}_{3}(2 \mathrm{M})$ solution. During dissolution, the sample was spiked with $1043 \sim 1.0 \mathrm{mg}$ of enriched ${ }^{35} \mathrm{Cl}$ carrier. Following complete dissolution, solid fluoride compounds were 1044 isolated from the sample solution by centrifuging. $\mathrm{AgCl}$ was precipitated through the addition of $1045 \mathrm{HNO}_{3}(0.15 \mathrm{M})$ and allowed to accumulate overnight. The precipitate was collected by 1046 centrifuging and subsequently dissolved in $30 \% \mathrm{NH}_{4} \mathrm{OH}$. $\mathrm{Cl}$ was extracted and impurities were 1047 removed through Anion Exchange Chromatography, and the final $\mathrm{AgCl}$ precipitate isolated 1048 through the addition of $0.1 \mathrm{M} \mathrm{AgNO}_{3}$ and $70 \% \mathrm{HNO}_{3}$. Each sample yielded approximately 3$10495 \mathrm{mg}$ of $\mathrm{AgCl}$. The $\mathrm{AgCl}$ pellet was rinsed with $18 \mathrm{M} \Omega \mathrm{H}_{2} \mathrm{O}$, dried overnight (12-16 hr.) at $70^{\circ} \mathrm{C}$, 1050 and loaded into $\mathrm{Cu}$ targets packed with $\mathrm{AgBr}$ for accelerator mass spectrometry (AMS) analysis. $1051{ }^{35 / 37} \mathrm{Cl}$ and ${ }^{36 / 37} \mathrm{Cl}$ ratios were measured via AMS at the Purdue Rare Isotope Measurement 1052 Laboratory at Purdue University, Indiana. 
1054

1055 (Tables A1 and A2 included as Excel files.)

1056 
Table A1. 10Be sample data

\begin{tabular}{|c|c|c|c|c|c|c|c|c|c|}
\hline Sample & $\begin{array}{l}\text { Latitude } \\
\text { deg }\end{array}$ & $\begin{array}{l}\text { Longitude } \\
\text { deg }\end{array}$ & $\begin{array}{c}\text { Elevation } \\
\mathbf{m}\end{array}$ & $\begin{array}{c}\text { Thickness } \\
\text { cm }\end{array}$ & $\begin{array}{l}\text { Density } \\
\text { g/cm3 }\end{array}$ & Shielding Factor & $\begin{array}{c}\text { Erosion Rate } \\
\mathbf{c m} / \mathbf{k y r}\end{array}$ & $\begin{array}{l}10 \mathrm{Be} \\
\text { at } / \mathrm{g}\end{array}$ & $\begin{array}{c}\text { 10Be uncertainty } \\
\text { at } / \mathrm{g}\end{array}$ \\
\hline Chaj-I2 & -23.03424 & -67.76790 & 4993 & 10.0 & 2.3 & 1 & 0 & $1.768 \mathrm{E}+06$ & $1.061 \mathrm{E}+05$ \\
\hline Chaj-I3 & -23.02242 & -67.82928 & 4585 & 5.0 & 2.3 & 1 & 0 & $9.915 \mathrm{E}+05$ & $3.966 \mathrm{E}+04$ \\
\hline Chaj-M1 & -22.98725 & -67.65284 & 4660 & 5.0 & 2.5 & 1 & 0 & $2.844 \mathrm{E}+06$ & $1.138 \mathrm{E}+05$ \\
\hline Chaj-M3 & -22.94925 & -67.68583 & 4802 & 10.0 & 2.5 & 1 & 0 & $5.024 \mathrm{E}+06$ & $1.507 \mathrm{E}+05$ \\
\hline Chaj-M5 & -23.02380 & -67.83113 & 4569 & 2.0 & 2.5 & 1 & 0 & $7.903 \mathrm{E}+06$ & $1.581 \mathrm{E}+05$ \\
\hline TAT-4 & -22.45470 & -67.99914 & 4533 & 5.0 & 2.3 & 0.998 & 0 & $1.157 \mathrm{E}+06$ & $4.626 \mathrm{E}+04$ \\
\hline Chaj-12-08 & -22.96808 & -67.66564 & 4702 & 5.0 & 2.5 & 1 & 0 & $3.9712 \mathrm{E}+05$ & $1.2192 \mathrm{E}+05$ \\
\hline Chaj-12-18 & -23.02044 & -67.83226 & 4564 & 5.0 & 2.3 & 1 & 0 & $2.3556 \mathrm{E}+06$ & $3.5098 \mathrm{E}+05$ \\
\hline Chaj-12-19 & -23.01647 & -67.81591 & 4719 & 5.0 & 2.3 & 1 & 0 & $9.1163 \mathrm{E}+05$ & $1.3036 \mathrm{E}+05$ \\
\hline Chaj-12-21 & -23.01327 & -67.81017 & 4787 & 5.0 & 2.3 & 1 & 0 & $5.3622 \mathrm{E}+06$ & $2.7186 \mathrm{E}+06$ \\
\hline
\end{tabular}




\begin{tabular}{|c|c|c|c|c|c|c|c|c|c|c|c|c|c|c|c|c|c|c|c|c|c|c|c|c|c|c|c|c|}
\hline Chaj-12-03 & -22.91785 & -67.76319 & 4784 & 5 & 2.5 & 1 & 0.0 & $\frac{p p m}{133.44}$ & $\frac{p p m}{15.31}$ & 2216.380 & 91.856 & 16.08 & 5.11 & 6.97 & & 3.59 & & 3.16 & 0.07 & 61.9 & 0.874 & $\frac{\mathrm{ppm}}{19.6}$ & $\frac{\mathrm{ppm}}{2.3}$ & $\frac{\mathrm{ppm}}{3.4}$ & $\frac{\mathrm{ppm}}{11.3}$ & $\frac{\mathrm{ppm}}{3.5}$ & $\frac{\mathrm{w} t \%}{0.215}$ & 0.005375 \\
\hline Chaj-12-04 & -22.91787 & -67.76275 & 4782 & 5 & 2.5 & 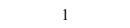 & 0.0 & 176.98 & 26.34 & 1336.530 & 49.867 & 16.39 & 5.14 & 6.01 & 2.36 & 2.66 & 0.075 & 3.24 & 0.06 & 62.76 & 0.725 & 24.6 & 2.5 & 3.3 & 12.9 & 4.1 & 0.29 & 0.00725 \\
\hline Chaj-12-06 & -22.988899 & -67.64395 & 4686 & 5 & 2.5 & 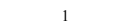 & 0.0 & 448.43 & 91.88 & 4933.290 & 145.779 & 14.25 & 4.91 & 6.67 & 2.49 & 3.02 & 0.104 & 2.71 & 0.09 & 62.37 & 0.617 & 38.2 & 3.1 & 3.6 & 17.1 & 7 & 1.145 & 0.028625 \\
\hline Chaj-12-08 & -22.96808 & -67.66564 & 4702 & 5 & 2.5 & 1 & 0.0 & 279.80 & 70.84 & 1899.670 & 69.866 & 15.17 & 4.38 & 5.58 & 2.47 & 2 & 0.071 & 3.07 & 0.08 & 63.12 & 0.653 & 23.7 &  & 4.1 & 15.3 & 5.9 & 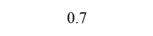 & 0.0175 \\
\hline Chaj-12-11 & -22.96558 & -67.79036 & 5036 & 5 & 2.5 & 1 & 0.0 & 70.75 & 2.32 & 2592.930 & & 16.84 & 5.71 & 6.46 & 2.16 & 2.84 & 0.077 & 3.31 & 0.03 & 59.53 & 0.772 & 14.4 & 2 & 3.1 & 11.5 & 3.6 & 0.2 & 0.00625 \\
\hline Chaj-12-12 & -22.96809 & -67.79295 & 5025 & 5 & 2.5 & 1 & 0.0 & 47.02 & 1.38 & 731.102 & 19.439 & 16.78 & 5.15 & 6.39 & 2.3 & 3.06 & 0.087 & 3.18 & 0.01 & 62.69 & 0.784 & 13.9 & 1.9 & 2.8 & 11.4 & 3.8 & 0.18 & 0.0045 \\
\hline Chaj-12-14 & -22.951 & -67.81497 & 4706 & 5 & 2.5 & 1 & 0.0 & 479.44 & 54.14 & 3647.480 & 91.950 & 15.26 & 4.64 & 5.84 & 2.51 & 2.52 & 0.079 & 3.07 & 0.1 & 61.78 & 0.751 & 27.3 & 2.8 & 4.1 & 13.6 & 4.2 & 0.835 & 0.020875 \\
\hline Chaj-12-15 & -22.95102 & -67.81488 & 4704 & 5 & 2.5 & 1 & 0.0 & 94.94 & 6.77 & 2073.030 & 43.473 & 15.25 & 4.64 & 6.03 & 2.49 & 3 & 0.089 & 2.83 & 0.06 & 63.17 & 0.759 & 27.3 & 2.5 & 3.5 & 12.9 & 5 & 0.545 & 0.013625 \\
\hline Chaj-12-18 & -23.02044 & -67.83226 & 4564 & 5 & 2.3 & 1 & 0.0 & 93.67 & 5.62 & 2625.590 & 60.105 & 15.47 & 4.32 & 4.86 & 2.67 & 1.22 & 0.055 & 3.2 & 0.06 & 64.59 & 0.587 & 32.1 & 2.3 & 2.8 & 14.5 & 6.1 & 0. & 0.010875 \\
\hline Chaj-12-19 & -23.01647 & -67.81591 & 4719 & 5 & 2.3 & 1 & 0.0 & 85.26 & 8.06 & 870.174 & 19 & 14.94 & 4.5 & 4.99 & 2.34 & 1.24 & 0.058 & 3.15 & 0.01 & 64.68 & 0.591 & 20.1 & 2 & 3 & 12.8 & 5.8 & 0.415 & 0.010375 \\
\hline Chaj-12-20 & -23.01366 & -67.81439 & 4758 & 5 & 2.3 & 1 & 0.0 & 117.77 & 6.59 & 1266.590 & 34.929 & 15.8 & 4.58 & 4.93 & 2.73 & 1.4 & 0.056 & 3.23 & 0.04 & 66.1 & 0.629 & 25.3 & 2.4 & 2.9 & 13.6 & 6.2 & 0.72 & 0.018 \\
\hline Chaj-12-21 & -23.01327 & -67.81017 & 4787 & 5 & 2.3 & 1 & 0.0 & 97.40 & 3.53 & 1038.020 & 26.026 & 15.56 & 4.54 & 4.97 & 2.33 & 1.23 & 0.061 & 3.1 & 0.03 & 64.71 & 0.624 & 27.8 & 2.3 & 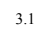 & 12.8 & 57 & 0 & 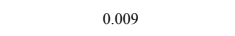 \\
\hline Chaj-M2 & -22.95012 & -67.68478 & 4796 & 5 & 2.5 & 1 & 0.0 & 347.20 & 92.79 & 2145.360 & 73.829 & 16.77 & 5.92 & 6.8 & 2.08 & 3.2 & 0.101 & 3.04 & 0.09 & 60.78 & 0.791 & 21.8 & 2.9 & 3.4 & 10 & 4.2 & 0.285 & 0.007125 \\
\hline
\end{tabular}




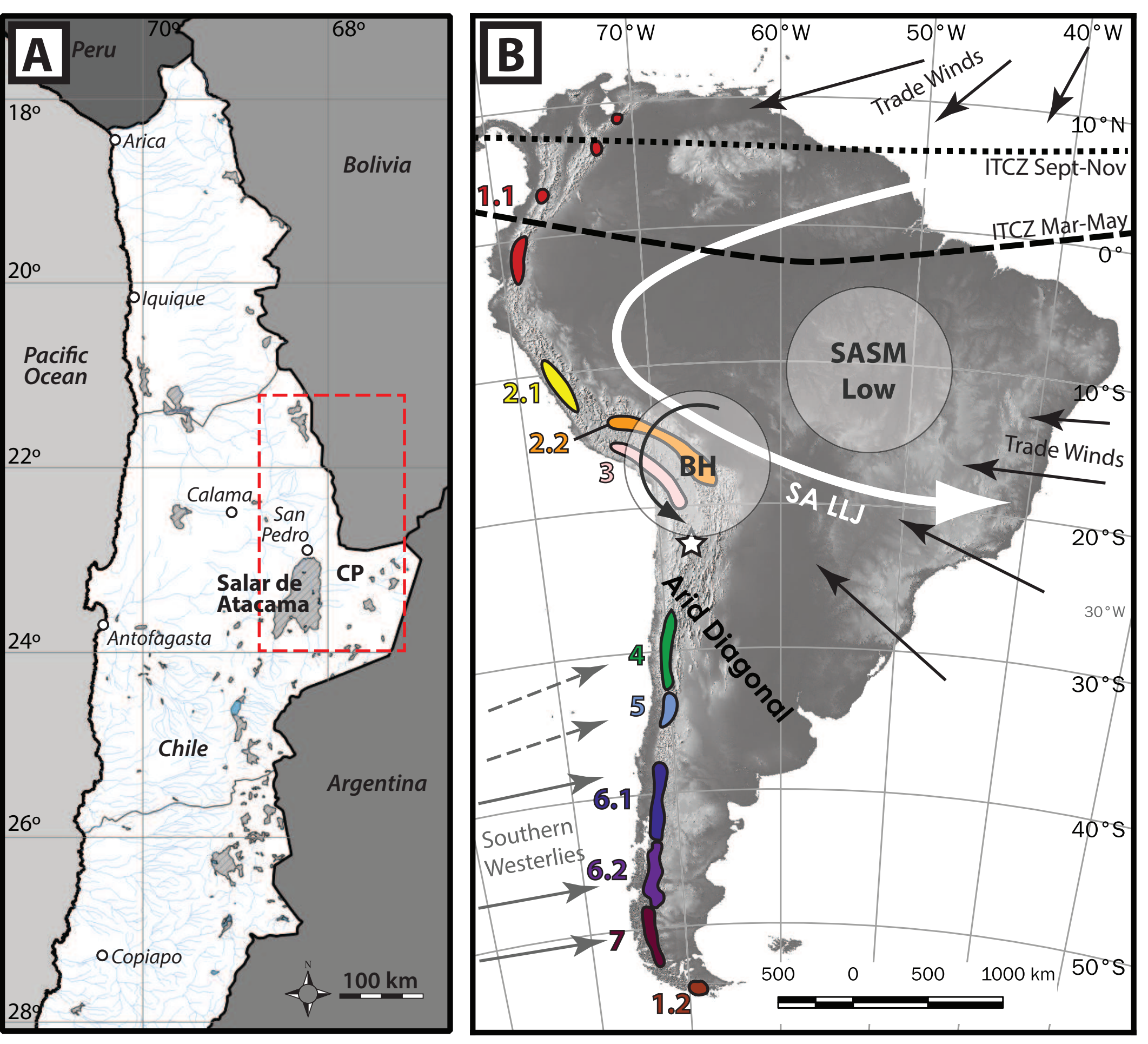




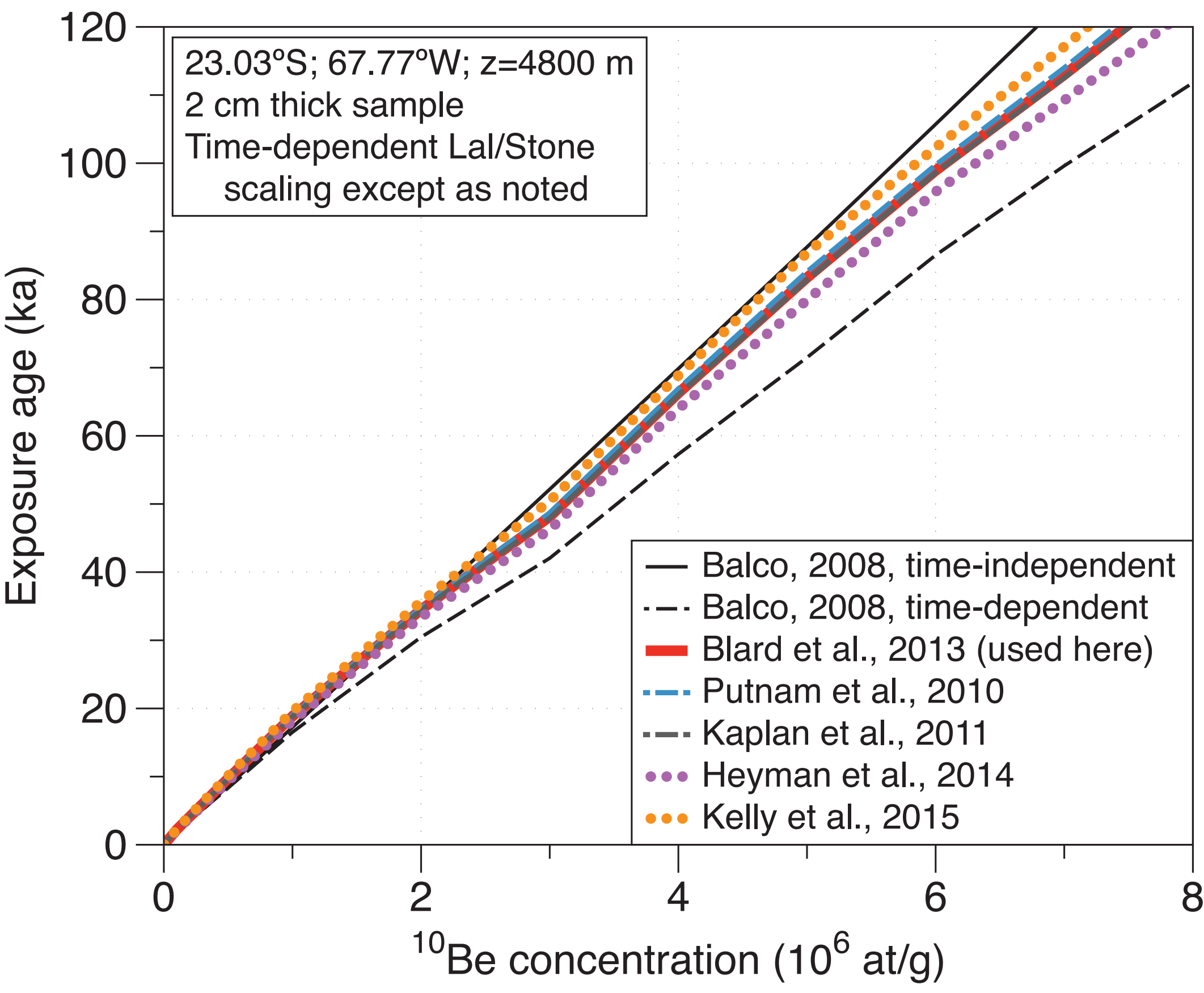




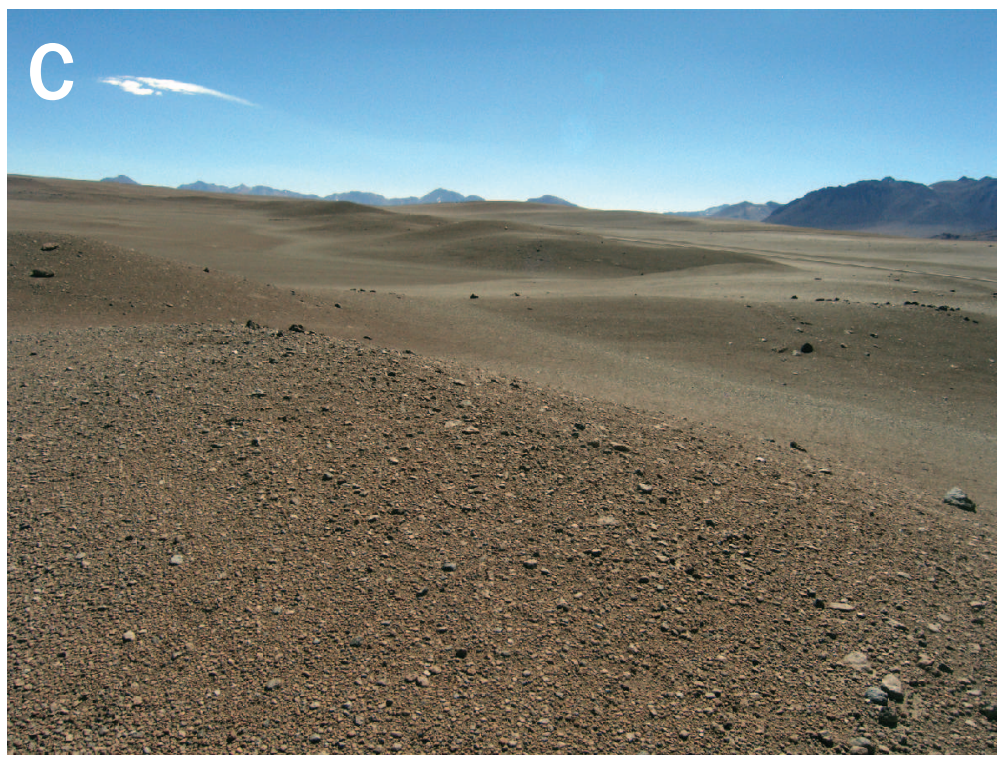

D

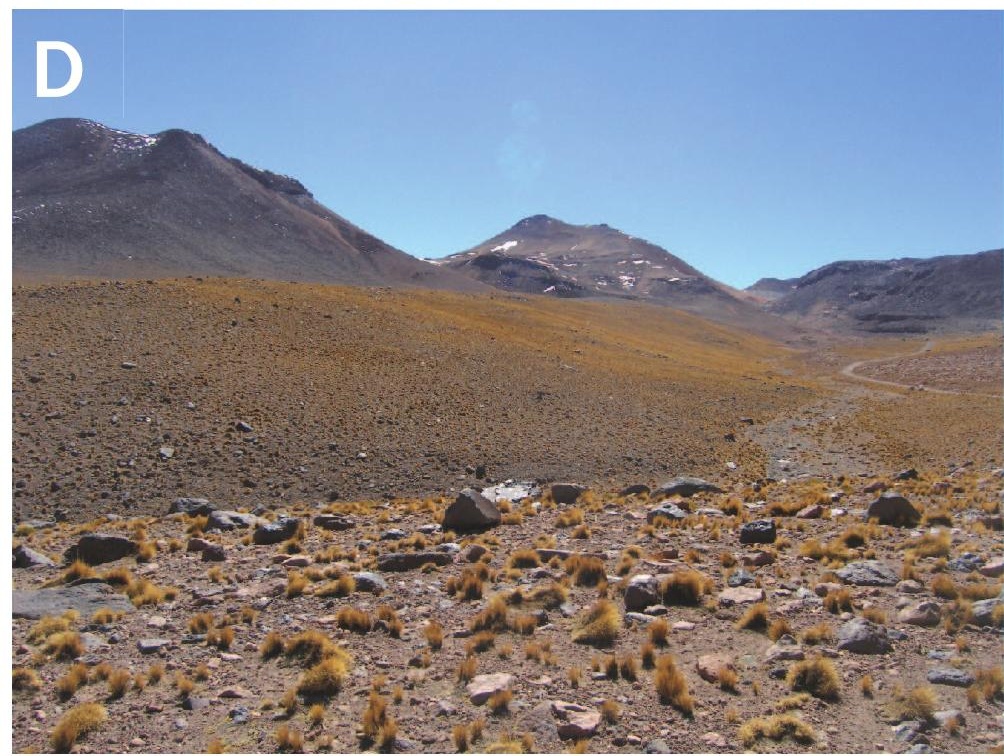

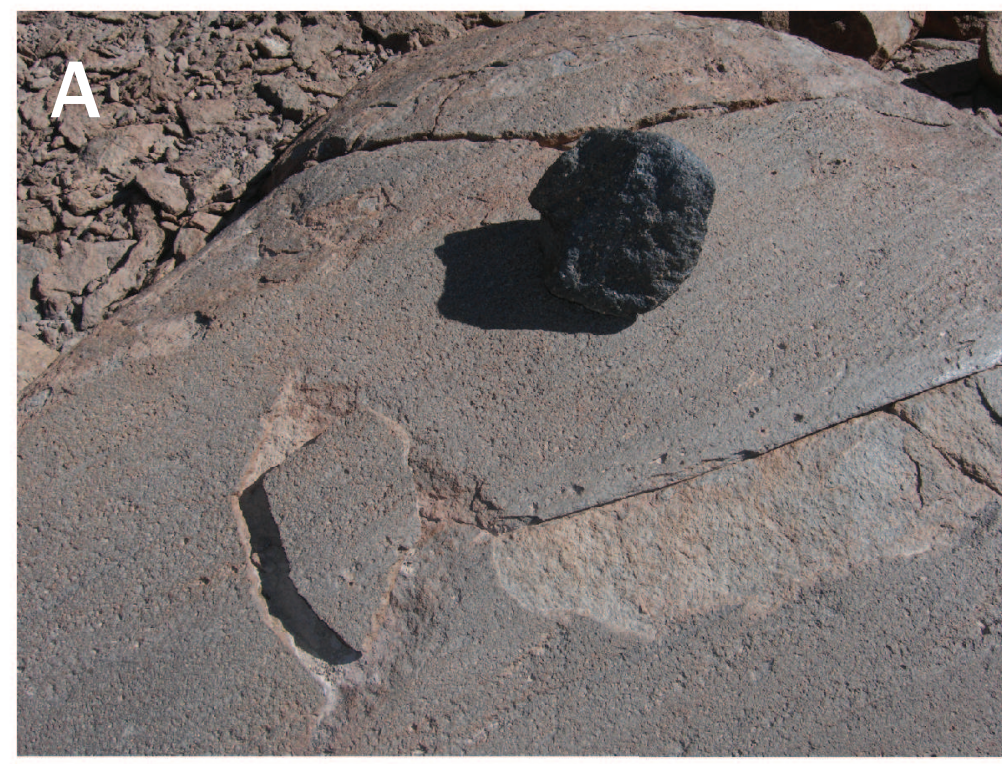

\section{B}

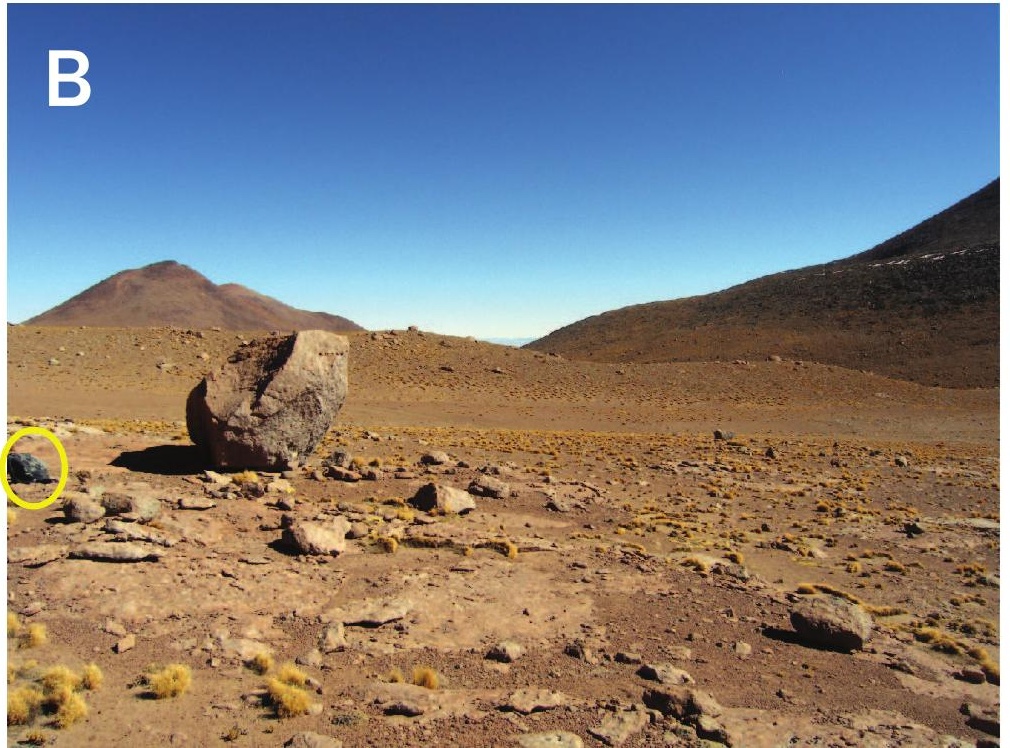

\section{Figure 4}

Fiqure 4 
Figure 5

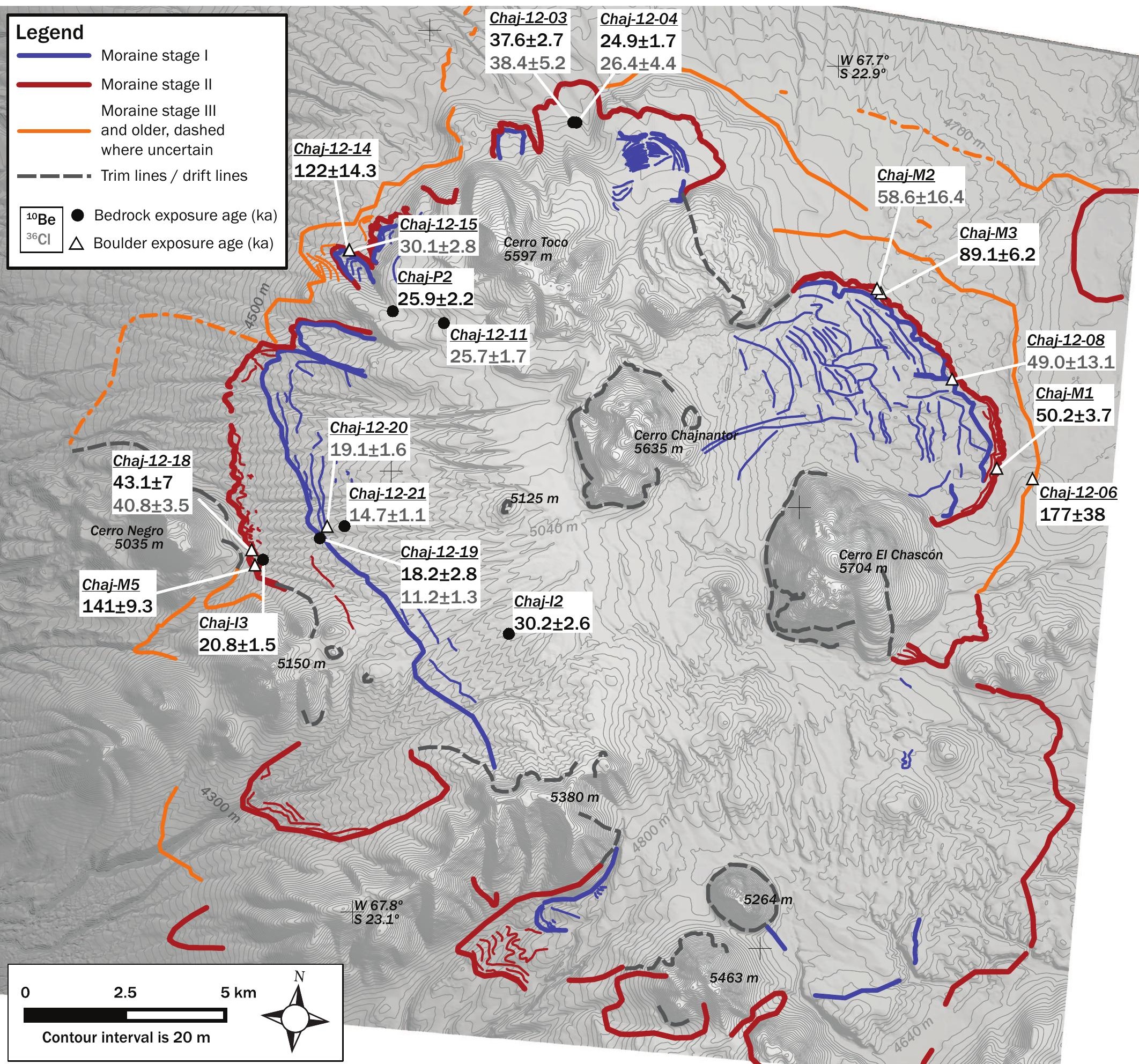




\section{Legend}

Moraine stage I

Moraine stage II

${ }^{10} \mathrm{Be}$ Bedrock exposure age (ka) ${ }^{36} \mathrm{Cl} \triangle$ Boulder exposure age $(\mathrm{ka})$
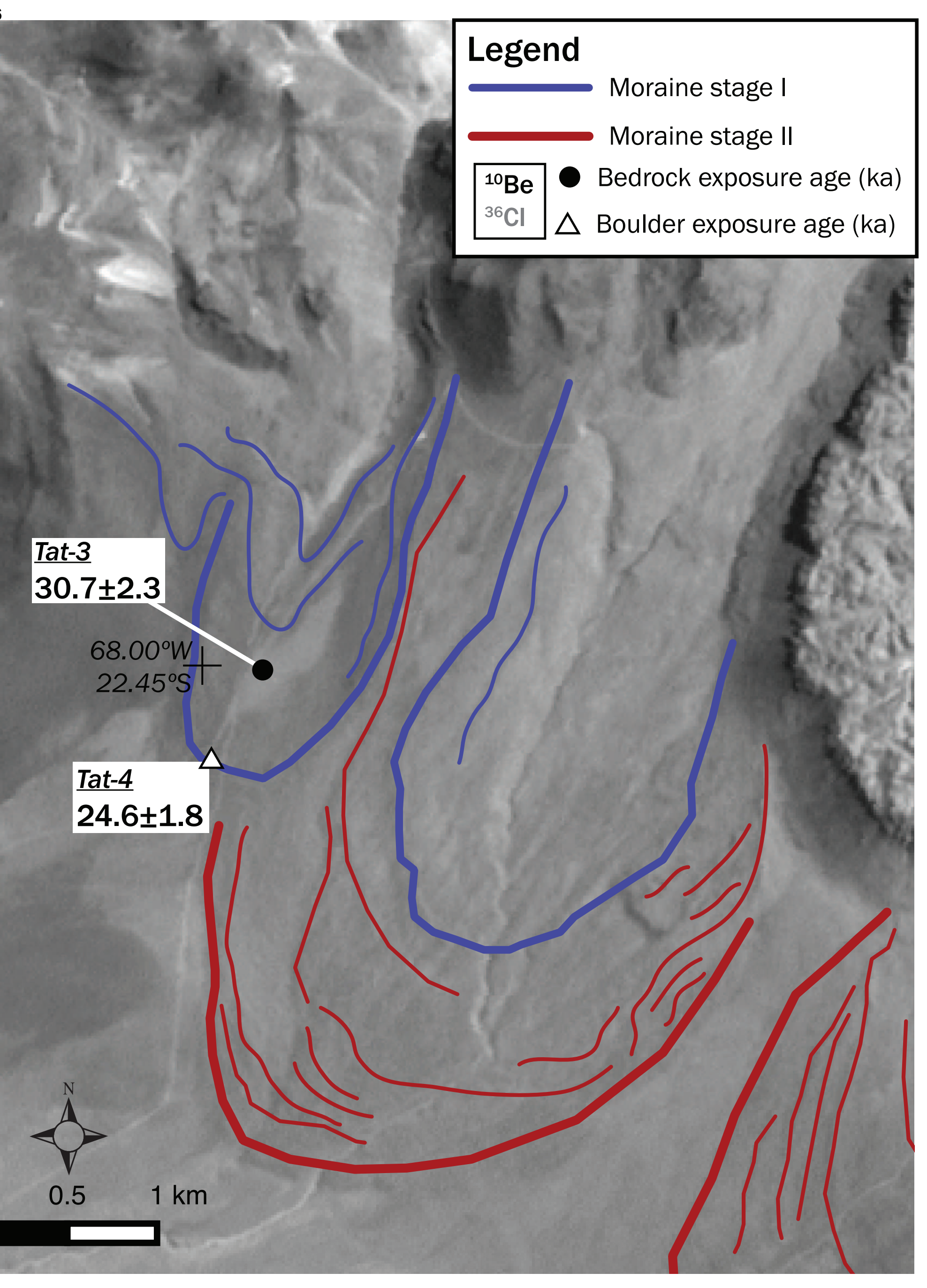

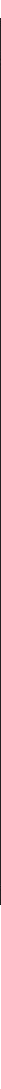

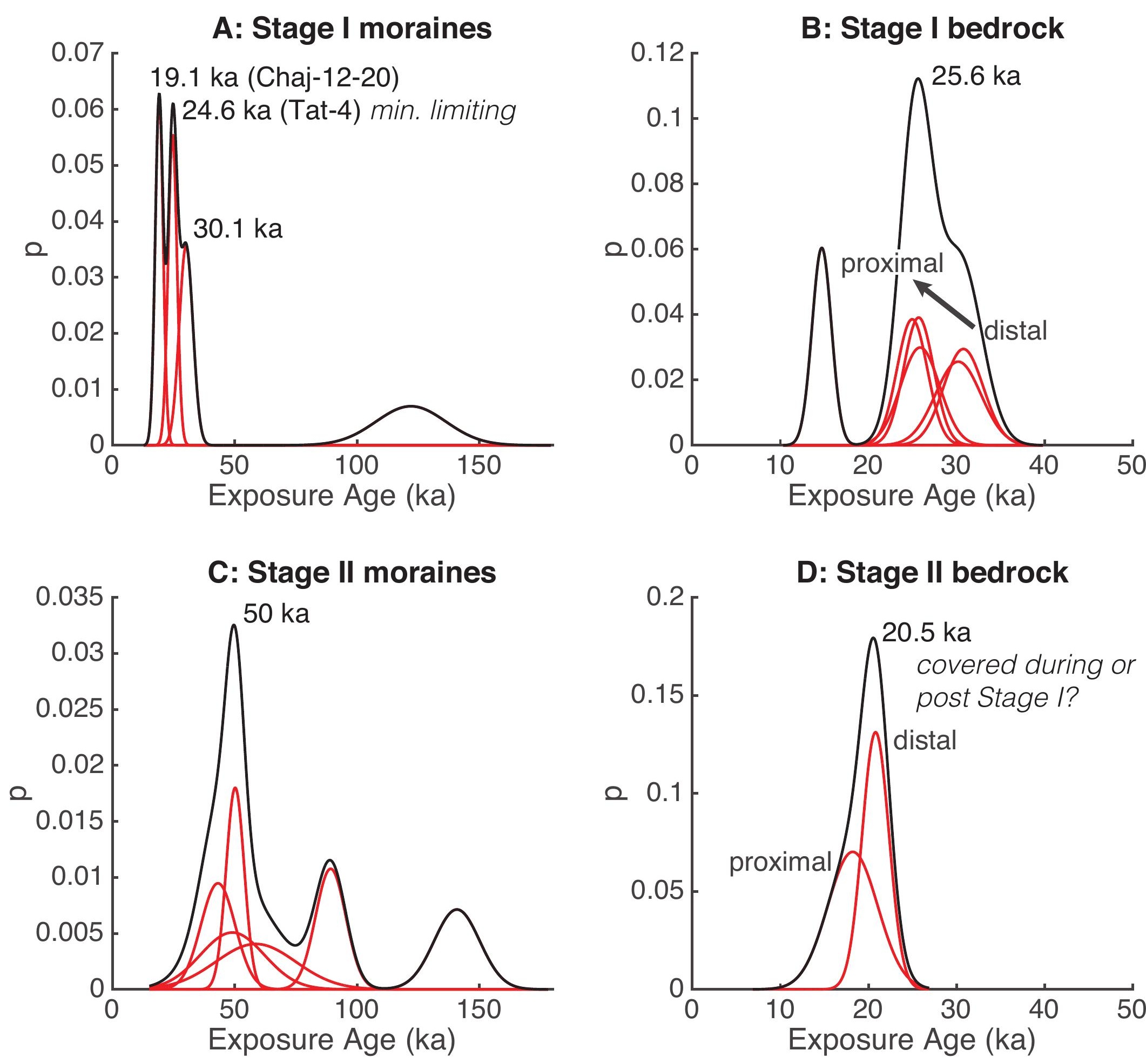
70-100 ka

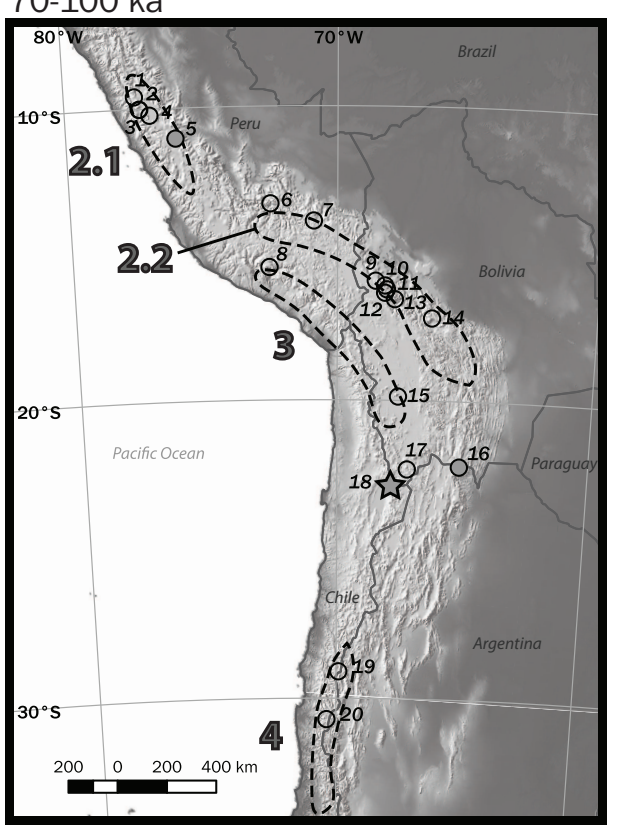

an

Before start of published record

\section{Clustered} ages; moraine abandonment

$\mathrm{F}$

$\bigcirc$ ages

0

No ages this period

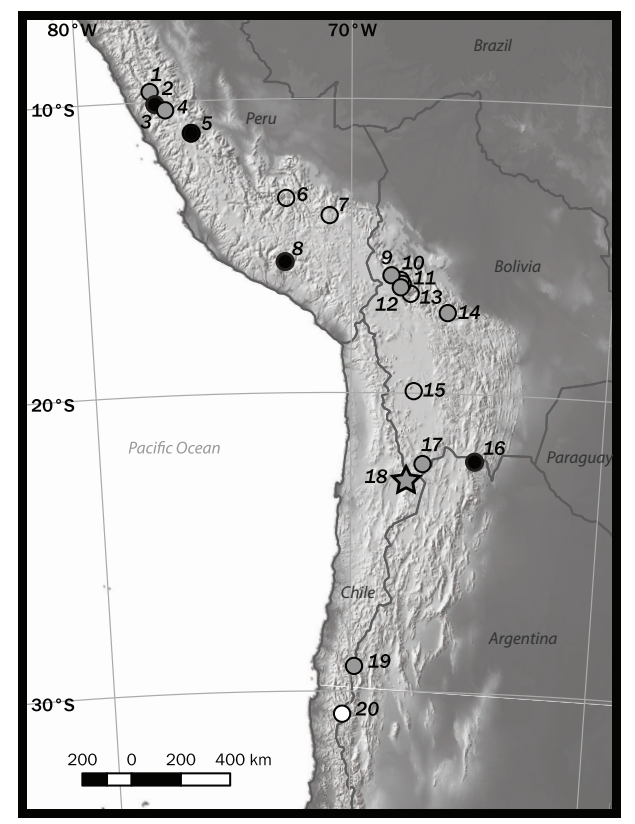

20-25 ka (LGM)
40-70 ka
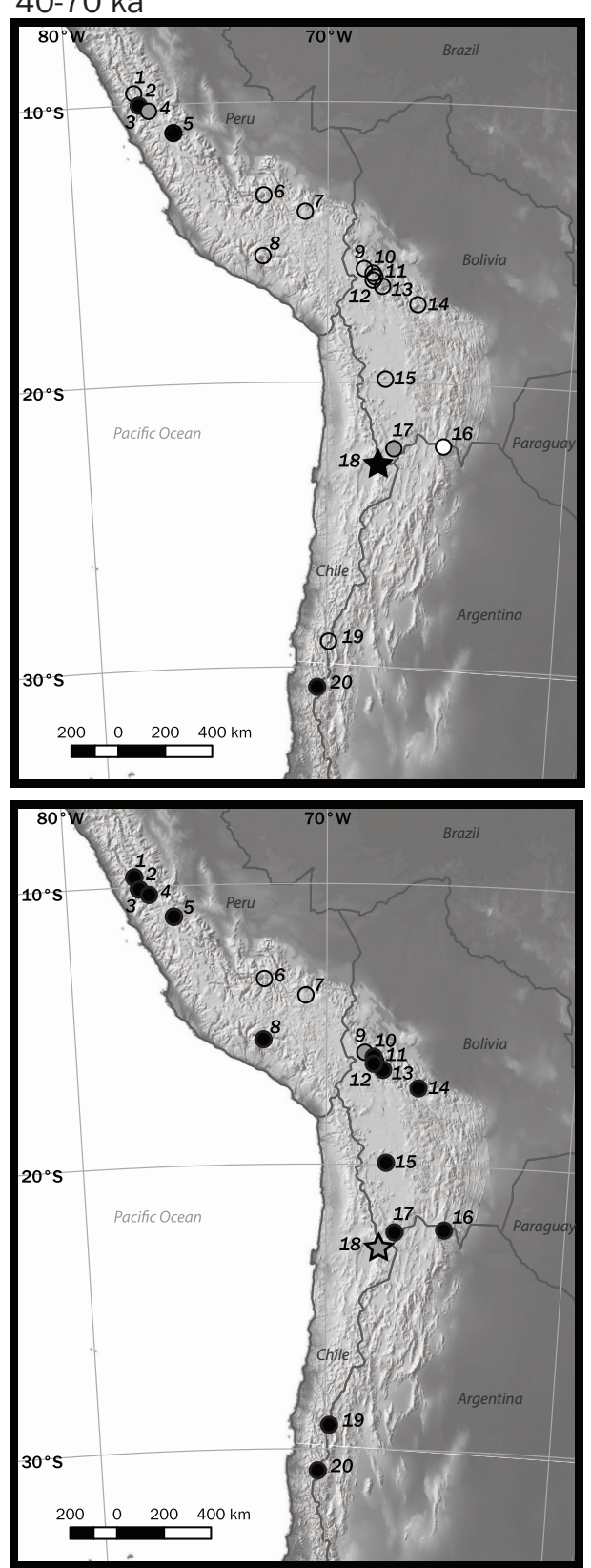

15-20 ka ( Tauca)
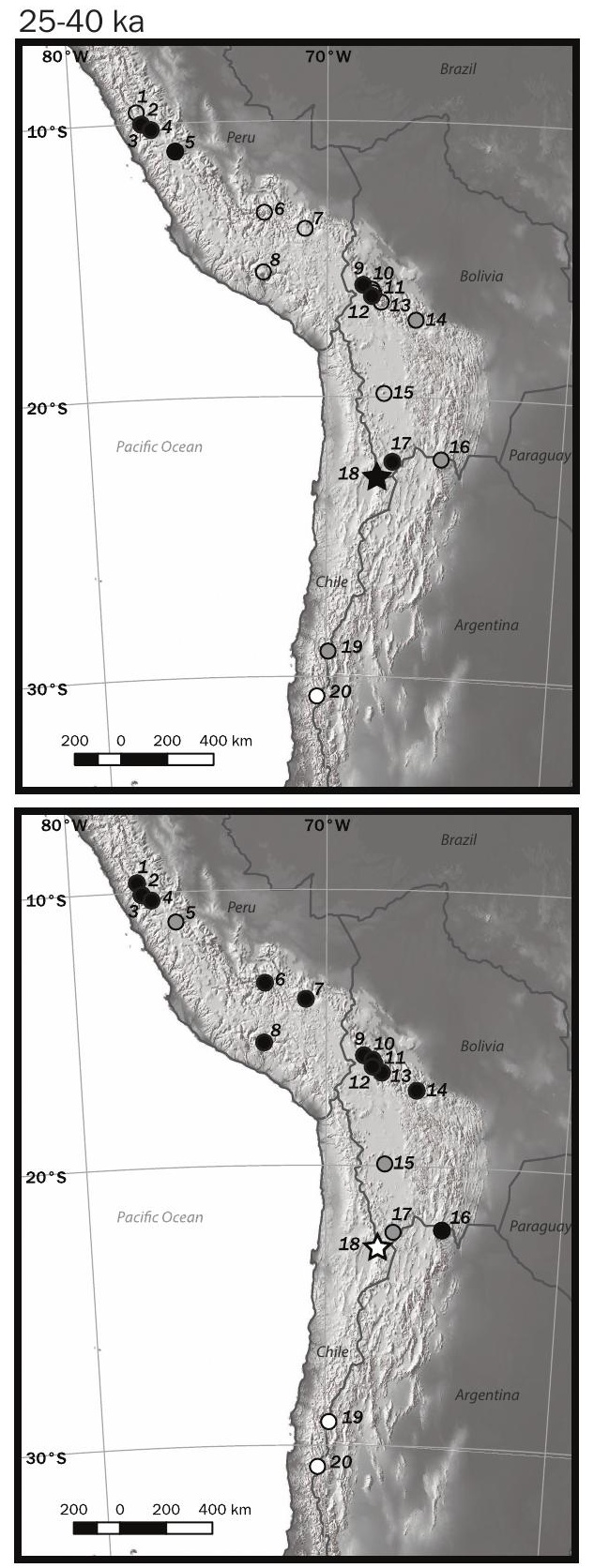

10-15 ka (Lateglacial) 




